[Vol. 129:738

\title{
COMMENT
}

\section{JUDIGIAL REVIEW AND THE TREND TOWARD MORE STRINGENT NLRB STANDARDS ON ARBITRAL DEFERRALS}

An employee is discharged under disputed circumstances. The employer contends that the employee was fired because she produced "low quality work," while the employee claims that the employer dismissed her because she engaged in union activities, and that the discharge therefore violated her statutory right to engage in such activities under section 8(a)(3) of the National Labor Relations Act (NLRA or the Act). ${ }^{1}$ The employee protests her termination and, in accordance with the grievance arbitration clause $^{2}$ contained in the applicable collective bargaining contract, the dispute is submitted to an arbitrator. The arbitrator upholds the discharge because "just cause" 3 for it was proven. The arbi-

129 U.S.C. $\$ 158(a)(3)$ (1976). This section makes it an unfair labor practice for an employer, "by discrimination in regard to hire or tenure of employment or any term or condition of employment to encourage or discourage membership in any labor organization." Id.

$2 \mathrm{~A}$ contract arbitration clause is a provision in a collective bargaining agreement typically providing that disagreements arising during the contract period, over the meaning of contractual terms are to be resolved by the submission of the disputes to an arbitrator-"an impartial person designated by the parties for just that purpose." Kaden, Judges and Arbitrators: Observations on the Scope of Judicial Review, 80 Colum. L. Rev. 267, 275 (1980). Professor Gorman has sketched the operation of these clauses:

Complaints of contract breach . . . are typically brought, by the union or the individual grievant, to a low-level supervisor in the first instance, and if unresolved to higher levels of supervision. If the dispute remains unresolved at the highest level of confrontation between union officials ... and company officials ... it will be submitted to an arbitrator, voluntarily selected by the parties to the contract.

R. GORMAN, Bastc Text on LaBor LAW 541-42 (1976). See generally [1976] LAB. REL. EXXPEDITER (BNA) 15.

A recent Bureau of National Affairs study of 400 collective bargaining agreements reported that $96 \%$ of the contracts surveyed provided for the arbitration of grievances. [1979] 2 Colnective BARgatnTNG-Negottations aNd Contracts (BNA) § 51:5.

$3 \mathrm{~A}$ general statement to the effect that an employee may be discharged for "cause," "just cause," or "proper cause" was found in $80 \%$ of the collective bargaining agreements surveyed by the Bureau of National Affairs. [1979] 2 CorLEGTtVe BargatNing-Negotiations aND Contracts (BNA) $\$ 40: 1$. These clauses

exclude discharge for mere whim or caprice. They are, obviously, intended to include those things for which employees have traditionally been fired. They include the traditional causes of discharge in the particular trade or industry, the practices which develop in the day-to-day 
tration award does not mention the employee's claim that her statutory rights were violated. Seeking vindication of her section $8(a)(3)$ claim, the employee files unfair labor practice charges with the National Labor Relations Board (NLRB or the Board). Basing its decision on its policy of dismissing unfair labor practice complaints when the allegedly illegal conduct has been the subject of a previous arbitration award, the Board dismisses the charges. The arbitration award is left as the final judgment in the dispute.

In the hypothetical situation just presented, ${ }^{4}$ the reason given for dismissal of the employee's complaint is a long-standing Board policy that is known as the "deferral doctrine." 5 Established in Spielberg Manufacturing Co., it permits an arbitrator, rather than the Board, to decide cases in which the statutory protections of the NLRA are at least partially at issue. The deferral issue arises only when the conduct complained of can be found violative of the NLRA despite the legality of the same conduct under a collective bargaining agreement. In the introductory hypothetical, for example, the Board could find that the employer committed a section $S(a)(3)^{7}$ violation even if the prior arbitration award upholds the employer's action as valid under the contract, because the contractual "just cause" standard under which the arbitrator evaluates an employer's actions is not identical to the standard under which the Board decides whether the action violates the statute. These "statutory rights" 8 disputes are typically brought before the Board as

relations of management and labor and most recently they include the decisions of courts and arbitrators. They represent a growing body of "common law" that may be regarded either as the latest development of the law of "master and servant" or, perhaps, more properly as part of a new body of common law of "Management and labor under collective bargaining agreements."

Worthington Corp., [1955] 24 LAB. ARB. Rep. (BNA) 1, 7 (McGoldrick \& Sutton, Arbs.).

4 This hypothetical fact situation closely resembles the facts of actual "deferral" situations. See, e.g., NLRB v. Pincus Bros., Inc.-Maxwell, 620 F.2d 367 (3d. Cir. 1980); NLRB v. Max Factor \& Co., 105 I.R.R.M. 2765 (9th Cir. Sept. $9,1880)$. See notes $41-66$ and 76 infra \& accompanying text.

5 "Deferral doctrine" and "deferral policy" are convenient phrases that are technically inaccurate, but they have traditionally been used by the Board and courts and will be used in this Comment. "Deferral" means postponement; e.g., postponement of a Board decision until after an arbitrator has decided the case. As will be seen below, however, the issue in this area of labor law is whether the Board will give deference to the arbitrator's decision on a statutory issue in a particular case. Thus, "deference policy" would be more accurate, but "deferral policy" is the accepted term of art.

6112 N.L.R.B. 1080 (1955). See notes 20-32 infra \& accompanying text.

729 U.S.C. $\$ 158(\mathrm{a})(3)$ (1976). See note 1 supra.

8 Although complaints brought before the Board alleging violations of statutory rights may also involve contractual issues, those complaints alleging violations of 
alleged violations of "individual" rights protected by sections $8(a)(1)$ and $8(a)(3)$ of the Act. ${ }^{9}$

In contrast to cases that involve both contractual and statutory questions, the outcomes of disputes that hinge solely upon an arbitrator's construction of a provision in a collective bargaining agreement do not involve NLRB deferral. In such disputes, the interpretation given the contract resolves the unfair labor practice issue, and no interpretation of the NLRA is necessary. ${ }^{10}$ For example, in a case alleging that an employer violated section $8(a)(5)^{11}$ by unilaterally-without prior bargaining with the union-changing wages or working conditions, the critical issue is whether the applicable collective bargaining agreement permits the employer's action. If the arbitrator determines that the contract does not require bargaining prior to the employer taking unilateral action concerning a particular term or condition of employment, then the employer's action will not have violated the Act. In this situation the arbitrator is merely performing his traditional function of determining the meaning and intent of contractual language. ${ }^{12}$ The Board's dismissal of the statutory claim does not involve "deferral" because the arbitrator has not interpreted and applied the Act in reaching his decision. ${ }^{13}$ Only if the contract had no provisions covering the duty of the employer to consult the union would the Act have to be relied upon to resolve the dispute.

the statute that can be decided independently of coexisting contractual issues are referred to throughout this Comment as statutory rights disputes.

929 U.S.C. $\$ 158(a)(1)$ \& (3) (1976). Under section $8(a)(1)$ it is an unfair labor practice for an employer "to interfere with, restrain, or coerce employees in the exercise of the rights guaranteed in" $\$ 7$ of the Act. Id. $\$ 158(\mathrm{a})(1)$. Section 7 protects employees" rights to "self-organization, to form, join, or assist labor organizations, to bargain collectively ... and to engage in other concerted activities for the purpose of collective bargaining, or other mutual aid or protection ...." Id. $\$ 157$ (1976). See note 112 infra. For the text of the relevant portion of $\$ 8(a)(3)$, see note 1 supra. 1980).

10 See, e.g., Bay Shipbuilding Corp., 251 N.L.R.B. No. 114 at 6-7 (Aug. 27,

1129 U.S.C. \$158(a)(5) (1976). This section states that it shall be an unfair labor practice for an employer, "to refuse to bargain collectively with the representatives of his employees." Id. Suits alleging the violation of this obligation to bargain are also typically brought by employers under $\$ 8(\mathrm{~b})(3)$ of the Act. 29 U.S.C. $\$ 158(\mathrm{~b})(3)$ (1976).

12 See United Steelworkers v. Warrier \& Gulf Navigation Co., 363 U.S. 574, 582 (1959). See also notes $39-88$ infra \& accompanying text.

13 This Comment is addressed to Board deferrals to arbitration awards when the conduct at issue is arguably violative of both an employee $\$ 7$ right and a contract provision, rather than those cases in which an interpretation of the contractual language will conclusively settle the issue. The latter situation does not really involve deferral at all, because the Board is not charged with the power to hear purely contractual disputes. See notes 23-25 infra \& accompanying text. 
Recently, the NLRB has retreated from its policy of deferring to arbitration in the former type of cases-those in which statutory violations could potentially be found regardless of the arbitrator's contract interpretation. This policy shift has been effected through a series of Board decisions limiting the circumstances under which it will defer to arbitration awards. ${ }^{14}$ In turn, the change in Board doctrine has evoked in several courts of appeals a more stringent application of their traditional standard of review of deferral decisions. ${ }^{15}$ In NLRB v. Pincus Brothers, Inc. - Maxwell, ${ }^{16}$ for example, the Third Circuit attempted to inhibit the NLRB's current retreat from its deferral policy by applying the widely-accepted "abuse of discretion" standard of judicial review of Board refusals to defer in a way that makes such refusals extremely difficult for the Board to justify.17 However, in NLRB v. Max Factor \& Co.18 -the first court of appeals decision rendered on this issue since Pincus Brothers-the Ninth Circuit expressly rejected the Third Circuit's rigorous application of its standard of review..$^{19}$

The conflict among the courts of appeals on the standard of review issue will be explored in this Comment in the context of a discussion of the changes that the Board has recently made in its deferral policy. First, this Comment discusses the Board's Spielberg policy of deferring to the decision of an arbitrator in cases involving statutory issues. Second, it analyzes the Third Circuit's treatment of deferral policy in Pincus Brothers in the context of the Board's recent attempts to limit the doctrine. Third, it examines the impact that the Board's policy shift will have on the roles that both the arbitrator and the NLRB will play in the determination of the legality of conduct that is arguably violative of both a collective bargaining contract and the NLRA. Finally, it will assess the relative merits of the Board's past and present deferral policies.

The Comment concludes that, due to the Board's failure to state explicitly its current deferral policy, the Pincus Brothers court

14 See text accompanying notes $118-44$ infra.

15 See note 72 infra.

16620 F.2d 367 ( 3 d Cir. 1980).

17 See notes 72-74 infra \& accompanying text. At least two other courts of appeals have recently placed similar restraints on the Board. See District II99E, Nat'l Union of Hosp. \& Fealth Care Employees v. NLRB, 613 F.2d 1102 (D.C. Cir. 1979); Douglas Aircraft Co. v. NLRB, 609 F.2d 352 (9th Cir. 1979). But see NLRB v. Max Factor \& Co., 105 L.R.R.M. 2765 (9th Cir. Sept. 9, 1980); Saint Luke's Memorial Hosp., Inc. v. NLRB, 104 L.R.R.M. 2788 (5th Cir. May 21, 1980); Alfred M. Lewis, Inc. v. NLRB, 587 F.2d 403, 407-08 (9th Cir. 1978).

18105 L.R.R.M. 2765 (9th Cir. Sept. 9, 1980).

10 Id. 2769 n.7. 
misinterpreted the Board's present view on arbitral deferral and established an inappropriate precedent governing the application of its standard of review of NLRB refusals to defer. A possible solution to this tension between the Board and some courts is offered. First, the Board should state explicitly that it has changed its "deferral" policy to something more akin to the "adoption" of arbitration results that comport with Board case law on any statutory issues implicated by the conduct underlying the complaint. Second, courts of appeals should review Board deferral decisions in a way that gives the Board more, rather than less, discretion to decide how to treat an arbitrator's award. This would comport with present Board law on deferral and would permit the Board to execute more effectively the public policy functions it has been charged with under the NLRA.

\section{The Roots of the Deferral Dogtrine}

The NLRB's practice of deferring to arbitration awards based upon conduct that is implicated in a subsequent unfair labor practice complaint was initiated in Spielberg Manufacturing Co.20 In that case, the Board dismissed a complaint alleging that an employer's refusal to reinstate four strikers violated sections $8(a)(1)$ and $8(a)(3)$ of the Act. ${ }^{21}$ This dismissal was based on the Board's recognition of a previously rendered arbitration award that did not require the reinstatement of the discharged employees. In the course of dismissing the unfair labor practice complaint, the Board established a set of standards for determining when deferral to an arbitrator's award is appropriate: it must be shown that "the [arbitration] proceedings appear to have been fair and regular, all parties had agreed to be bound [by the arbitration award], and the decision of the arbitration panel is not clearly repugnant to the purposes and policies of the Act." 22

By claiming to defer to arbitration awards in a given case only if the three criteria stated above are met, the NLRB was implicitly

20112 N.L.R.B. 1080 (1955). Prior to this decision the Board and the courts of appeals had considered the issue of deference to arbitration awards, but had not established any explicit set of guidelines. See, e.g., NLRB v. Walt Disney Prods., 146 F.2d 44, 48 (9th Cir. 1945), cert. denied, 324 U.S. 877 (1946); Wertheimer Stores Corp., 107 N.L.R.B. 1434 (1954); Monsanto Chem. Co., 97 N.L.R.B. 517, 519-20 (1951), enforced, 205 F.2d 763 (8th Cir. 1953); Timken Roller Bearing Co., 70 N.L.R.B. 500 (1946), rev'd on other grounds, 161 F.2d 949 (6th Cir. 1947).

21112 N.L.R.B. at 1082. See notes 1 \& 9 supra.

22112 N.L.R.B. at 1082. 
attempting to accommodate the tension it erroneously perceived between two statutory provisions, section 10(a) of the NLRA and section 203(d) of the Labor Management Relations (Taft-Hartley) Act (LMRA). Section 10(a) is designed to protect an employee's statutory rights. It empowers the Board "to prevent any person from engaging in any unfair labor practice . . . affecting commerce. This power shall not be affected by any other means of adjustment or prevention that has been or may be established by agreement, law, or otherwise . . . ."23 Section 203(d) of the LMRA is designed to encourage the voluntary adjustment of contractual disputes. This section states that "[f]inal adjustment by a method agreed upon by the parties is declared to be the desirable method for settlement of grievance disputes arising over the application or interpretation of an existing collective bargaining agreement." 24 There is no statutory reason why the Board cannot, in the context of deciding a statutory rights dispute, accept an arbitrator's prior decision on a related contractual question while refusing to give any deference to the arbitrator's decision on the statutory issue. ${ }^{25}$ That the Board in Spielberg developed guidelines for deferring to such statutory decisions perhaps demonstrates that it was trying to balance sections $10(a)$ and $203(d),{ }^{26}$ a process it should not have undertaken. ${ }^{27}$

The accommodation reached in Spielberg between these two statutory provisions was expressly designed to encourage the voluntary adjustment of labor disputes through arbitration. ${ }^{28}$ Under the Spielberg criteria, unless the arbitrator's award is so irrational as to be "palpably wrong," the Board adopts the arbitrator's decision as controlling on the unfair labor practice issue presented it. ${ }^{29}$

2329 U.S.C. $\$ 160$ (a) (1976) (emphasis added).

2429 U.S.C. $\$ 173$ (d) (1976) (emphasis added).

${ }^{25}$ Indeed, in dictum, the Supreme Court has spoken of the value of this type of complementary decisionmaking. See Alexander v. Gardner-Denver Co., 415 U.S. 36; notes $145-49$ infra \& accompanying text.

20 This statutory balancing process was explicitly acknowledged by the Board in at least two later cases: Collyer Insulated Wire, A Gulf \& Western Systems Co., 192 N.L.R.B. 837, 840 (1970), and International Harvester Co., 138 N.L.R.B. 923, 925-26 (1962), enforced sub nom. Ramsey v. NLRB, 327 F.2d 784 (7th Cir.), cert. denied, 377 U.S. 1003 (1964).

${ }^{27}$ See notes 171-79 infra \& accompanying text.

2s The Board stated in Spielberg that "we believe that the desirable objective of encouraging the voluntary settlement of labor disputes will best be served by our recognition of the arbitrator's award." 112 N.L.R.B. at 1082.

29 See, e.g., International Harvester Co., 138 N.L.R.B. 923, 928-29 (1962), enforced sub nom. Ramsey v. NLRB, 327 F.2d 784 (7th Cir.), cert. denied, 377 U.S. 1003 (1964). 
Mere disagreement is not a ground for ignoring the award, ${ }^{30}$ nor can the Board simply "shrug off" the conclusions of the arbitrator. ${ }^{31}$ Only when the award clearly does not meet the Spielberg standards will the Board disregard an arbitrator's decision and decide the case itself. ${ }^{32}$

This deferral policy was, significantly, extended in Collyer Insulated Wire, $A$ Gulf \& Western Systems Co. ${ }^{33}$ to disputes that had not even been submitted to arbitration. In Collyer, the union filed a charge with the NLRB that the employer had violated sections $8(a)(1)$ and (5) of the NLRA by making unilateral changes in wages and working conditions. ${ }^{34}$ The case turned on whether or not the collective bargaining contract, which contained a grievance arbitration clause, authorized the employer to make such changes. ${ }^{35}$ The Board dismissed the unfair labor practice complaint so that the parties could have an opportunity to resolve their contractual dispute through the arbitration process. ${ }^{36}$ In order to eliminate the risk of prejudice to any party and to insure compliance with the Spielberg standards, however, the Board retained jurisdiction of the dispute

solely for the purpose of entertaining an appropriate motion for further consideration upon a proper showing that either (a) the dispute has not, with reasonable promptness after the issuance of this decision, either been resolved by amicable settlement in the grievance procedure or submitted promptly to arbitration, or (b) the grievance or arbitration procedures have not been fair and regular or have reached a result which is repugnant to the Act. ${ }^{37}$

30 See, e.g., Pincus Bros., Inc., 237 N.L.R.B. 1063, 1064 (1978), enforcement denied on other grounds, 620 F.2d 367 (3rd Cir. 1980); Hawaiian Hauling Service, L.d., 219 N.L.R.B. 765, 766 (1975), enforced, 545 F.2d 674 (9th Cir. 1976), cert. denied, 431 U.S. 965 (1976).

31 NLRB v. Wilson Freight Co., 604 F.2d 712, 723 (1st Cir. 1979), cert. denied sub nom. Smith v. Wilson Freight Co., 445 U.S. 962 (1980).

32 See, e.g., United Steelworkers Local 7450 (Asarco, Inc.), 246 N.L.R.B. No. 139 (Dec. 7, 1979) (no deferral where employee grievant not a party to arbitration hearing); Mason and Dixon Lines, Inc., 237 N.L.R.B. 6 (1978) (no deferral where arbitration panel is biased and the proceedings unfair); Kansas Meat Packers, 198 N.L.R.B. 543 (1972) (no deferral where interests of employee grievants were in conflict with the union representing them at arbitration hearing).

33192 N.L.R.B. 837 (1971).

34 Id. See notes 9 \& 11 supra.

35192 N.L.R.B. at 839 ("this dispute in its entirety arises from the contract"). 36 Id. $839,841$.

37 Id. 843 (footnote omitted). 
Thus, Collyer formally established the practice-for cases in which a contractual decision might alleviate the need for a statutory adjudication-of the Board refraining from deciding disputes brought before it until the arbitration process had been given a chance to work. The NLRB claimed that this procedure "guarantee[s] that there will be no sacrifice of statutory rights if the parties' own processes fail to function in a manner consistent with the dictates of our law." 38 Nonetheless, the standards that the Board enunciated in Spielberg and Collyer made clear that the Board intended to grant a considerable degree of deference to arbitration awards and to the arbitration process. ${ }^{39}$

\section{JUDICIAL ENFORCEMENT OF THE Spielberg DoctrunE: NLRB v. Pincus Brothers, Inc.-Maxwell}

\section{A. The Decision}

The Board's current deferral policy was recently analyzed by the Third Circuit in NLRB v. Pincus Brothers, Inc.-Maxwell. ${ }^{40}$ Pincus Brothers, Inc.-Maxwell (Pincus), a Philadelphia manufacturer and wholesale distributor of men's clothing, terminated a twoyear employee, Jane Richardson, in February of 1977.11 Richardson protested her dismissal, which had been precipitated by her preparing and distributing during both working and nonworking time a leaflet critical of Pincus's salary levels. ${ }^{42}$ The firing was upheld by an arbitrator, who found that Richardson "had abused working time," and that the leaflet Richardson distributed intentionally misrepresented facts relating to Pincus's practices in a manner that constituted "unprotected disloyalty." ${ }^{43}$

$38 \mathrm{Id}$.

${ }^{39}$ Additional evidence of the Board's favorable attitude toward arbitration during that general time period can be found in Electronic Reproduction Service Corp., 213 N.L.R.B. 758 (1974). There, the Board announced that, absent unusual circumstances, any statutory issues presented to it in deferral cases would be presumed to have been decided by the arbitrator, regardless of whether such issues actually had been considered. See text accompanying notes 133 \& 134 infra.

It is noted that, because this Comment focuses on the Pincus Brothers decision and its review of refusals to defer to arbitration awards, the Comment's discussion will concentrate on that type of refusal, rather than refusals to defer under Collyer. 40620 F.2d 367 (3d Cir. 1980).

41 Id. 370.

42 The one-page leaflet, entitled "We Won't SAcrufice for Pincus' Profirs," referred to a recent plant meeting as a "circus" and accused Pincus of attempting to cut the workers" "already stinking pay checks." Id. 370-71.

43 Id. 371. The arbitrator's latter finding signifies that he examined Richardson's claim that her $\$ 7$ rights were violated, but concluded that her activities 
While the grievance was pending, Richardson filed a section $8(a)(1)^{44}$ charge with the Board, ${ }^{45}$ claiming that she had been discharged for engaging in protected activity. After thoroughly examining the facts found by the arbitrator, the Board refused to defer to his award upholding the discharge on the ground that "the arbitrator's findings that Richardson's conduct was unprotected [by the NLRA] are so clearly in error that it would be repugnant to the policies of the Act to defer to them." 46 The case was remanded to an administrative law judge, who found that Pincus had violated section $8(a)(1) .{ }^{47}$ The Board affirmed this decision, ${ }^{48}$ and sought enforcement of its order in the court of appeals, but the Third Circuit panel denied enforcement. ${ }^{49}$

The issue facing the court was whether the Board should have deferred to the arbitration award.50 The panel's analysis was directed toward determining the appropriate standard of review of Board refusals to defer. The three-judge panel issued three separate opinions. Judge Rosenn's "majority" opinion held that the Board's refusal to defer could be overturned only if it constituted an abuse of discretion..$^{51}$ Judge Rosenn found that " $[\mathrm{b}]$ ased on the Board's. Spielberg doctrine, congressional action, and judicial decisions, . . . it is an abuse of discretion for the Board to refuse to defer to an arbitration award where the findings of the arbitrator may arguably be characterized as not inconsistent with Board policy." 52 Applyingthis standard, he concluded that the Board's refusal to defer in the instant case was an abuse of discretion because Richardson's leaflet-

were outside the scope of-and thus unprotected by- $\$ 7,29$ U.S.C. $\$ 157$ (1976). See note 9 supra. See generally R. Gorman, supra note 2, at 296-325.

44 NLRA $\$ 8(a)(1), 29$ U.S.C. $\$ 158(a)(1)$ (1976). See note 9 supra.

45 For an outline of the procedural steps needed to be taken for a complaint to reach the stage of Board consideration, see note 62 infra.

46 Pincus Bros., Inc., 237 N.L.R.B. 1063, 1065 (1978). The decision of the panel, consisting of Members Jenkins, Murphy, and Truesdale, was unanimous.

$47620 \mathrm{~F} .2 \mathrm{~d}$ at 371 . The administrative law judge initially hears unfair labor practice cases in a "court-like proceeding" and prepares a decision. If exceptions to the administrative law judge's decision are filed, the Board will formally review the case. R. Gorman, supra note 2 , at 8 .

$48620 \mathrm{~F} .2 \mathrm{~d}$ at 371 .

$40 \mathrm{Id} .377$.

50 Id. 369-70.

51 Id. 372. This standard has been employed by several other courts of appeals. See NLRB v. Max Factor \& Co., 705 L.R.R.M. 2765 (9th Cir. Sept. 9, 1980); Hawaiian Hauling Service, Ltd. v. NLRB, 545 F.2d 674, 676 (9th Cir.), cert. denied, 431 U.S. 965 (1976); NLRB v. Cincinnati Local 271, Lithographers \& Photoengravers Int'l Union, 495 F.2d 763 (6th Cir. 1974); NLRB v. Hribar Trucking, Inc., 406 F.2d 854, 858 (7th Cir. 1969).

52620 F.2d at 374 . 
ting was "arguably unprotected activity." 53 The arbitrator's award upholding the dismissal was therefore not "clearly repugnant" to the Act. ${ }^{54}$

Judge Garth, concurring, reasoned that the Board "was compelled under its Spielberg doctrine to defer to the arbitrator's award." 65 Unlike Judge Rosenn, however, Judge Garth believed that the appropriate standard of judicial review is "legal error." sB Although accepting the view that "national labor policy confers, as an initial matter, discretion on the Board in formulating a position on deference to arbitration awards," ${ }_{57}$ Judge Garth contended that the Board had exercised that discretion by adopting the Spielberg standards. ${ }^{58}$ If an arbitration award meets those standards, Board deferral is required as a matter of Jaw, ${ }^{59}$ and matters of law are reviewed under a legal error standard. ${ }^{60}$

$53 \mathrm{Id}$. 375. Judge Rosenn found four possible grounds on which to conclude that Richardson's conduct was unprotected: (1) an employee loses the protection of the Act when he or she makes "deliberately or maliciously false" statements, and Richardson's conduct could arguably have been characterized as such; (2) Richardson's conduct might have constituted unprotected disloyalty; (3) Richardson's conduct might have been inconsistent with the Act's "fundamental goal of encouraging collective bargaining and industrial stability;" (4) it is "at least arguable" that Richardson's action, "motivated by personal pique," was not concerted activity. Id. 375-77.

54 See Spielberg Mfg. Co., 112 N.L.R.B. 1080, 1082 (1955); text accompanying note 22 supra.

55620 F.2d at 377 (Garth, J., concurring).

56 Id. See note 60 infra. Judge Garth acknowledged that "all of the courts that have expressed themselves on the issue have indicated that the Board's application of the Spielberg doctrine is reviewed under an abuse of discretion standard," but found none of those opinions "compelling." 620 F.2d at 377.

57620 F.2d at 377 (Garth, J., concurring) (emphasis in original).

58 Id. 379.

59 Id. 383.

$60 \mathrm{Id}$. 380. The distinction between the abuse of discretion and legal error standards of review is potentially significant. Under the former, the leeway given the Board in deciding whether to defer varies dramatically from court to court. It may be very limited, as in Pincus Brothers, where the Board is left with the choice of either deferring to the award in a given case or proving that there is no way to rectify it with the Act. See text accompanging note $\mathbf{5 2}$ supra. Conversely, the discretion allowed may be very considerable, as in NLRB v. Max Factor \& Co., where the Board is, in essence, permitted to interpret and apply its own precedents in any way it sees fit, as long as the deferral decision at issue can be seen as being reasonable. 105 L.R.R.M. 2765, 2768, 2769 n.7.

While the abuse of discretion formulation does little to standardize the degree of discretion afforded the Board by various courts of appeals, Judge Garth's legal error standard seems to admit of but one reading: no Board discretion is permitted in determining whether the arbitration proceeding and subsequent award have met the Spielberg criteria. The court of appeals is free to review the issue de novo, and reverse the Board's decision upon simple disagreement with it. 620 F.2d at 380 . Because of Judge Rosenn's narrow application of the abuse of discretion formulation, the two standards discussed and used by the Pincus Brothers majority are indistinguishable in their effect, but a contrast with the Ninth Circuit's application of the abuse of discretion standard amply demonstrates how much more deference the Board is generally given under it rather than its Pincus Brothers counterpart. 
Judge Gibbons, dissenting, argued that, except in a small class of unfair labor practice cases, ${ }^{61}$ the NLRB does not have the statutory authority to defer to an arbitration award once its General Counsel has issued a complaint." ${ }^{22}$ The General Counsel has "unreviewable prosecutorial discretion [and] it is hard to find in the structure of the Act the authority for the Board to second guess the exercise of that discretion." 63 Judge Gibbons found further support for his view by examining the public policy function of the Act. He noted that the Board, not an arbitrator, is responsible for interpreting and enforcing the Act. ${ }^{64}$ Because an arbitration award will be able to do justice only in the individual case, "a remedy selected by an arbitrator in processing an individual grievance may be wholly inadequate to enforce the public policy against unfair labor practices." 65 Judge Gibbons concluded that it would be incorrect for the Pincus Brothers court to insist on Board deference to an arbitration award after both the General Counsel and the Board decided that deference was not in the public interest. ${ }^{68}$

61 Judge Gibbons stated that the Board has the statutory authority to defer to arbitration only in work jurisdiction disputes, because only in that type of unfair labor practice situation is arbitration specially provided for by statute. 620 F.2d at 387. Section 10(k) of the NLRA, 29 U.S.C. $\$ 160(\mathrm{k})$ (1976), provides for Board adjudication of such disputes unless the parties agree upon settlement or arbitration within 10 days after notice of the filing of the charge.

Judge Gibbons also recognized that there is a distinction between contractual and statutory disputes. See notes 4-13 supra \& accompanying text. He stated that deferral may be appropriate in disputes in which "the predicate for the charge may be entirely dependent upon the meaning of a collective bargaining contract .... In such a case, which involves a pure contract dispute, once the terms of the contract are determined the public interest in the matter ends." Pincus Bros., 620 F.2d at 391 (Gibbons, J., dissenting). Deferral under the latter exception was, according to Judge Gibbons, not appropriate: resolution of the employee's claim was not dependent "upon the meaning of a collective bargaining contract . . . [because] even if a contract remedy is available the conduct complained of is independently illegal, and cannot be made legal regardless of the contract's terms." Id. See text accompanying notes 106-17 \& 145-49 infra.

62 With regard to unfair labor practice complaints, the NLRB has three distinct functions. A complaint must be directed first to a NLRB regional office, where it will be investigated and, hopefully, resolved without litigation. If not, the regional director may assume the role of prosecutor, issuing a complaint if he feels the claim is meritorious. A regional director's decision not to issue a complaint is appealable to the General Counsel's Office, which has the ultimate prosecutorial authority, because its decision on the matter is nonreviewable. Vaca v. Sipes, 386 U.S. 171, 182 (1967). The NLRB's third function, adjudication, is carried out by administrative law judges and, on appeal, the Board itself. See generally R. Gorman, supra note 2 , and $7-9$. On how this procedure applies to deferral cases, see generally Pincus Bros., 620 F.2d at 385-86 (Gibbons, J., dissenting); Truesdale, Is Spielberg Dead?, [1978] N.Y.U. ConF. ON LAB. 47, 52; note 195 infra (quoting Truesdale, supra).

63 Pincus Bros., 620 F.2d at 386 (Gibbons, J., dissenting).

64 Id. 389.

65 Id. 390.

${ }^{66} \mathrm{Id} .399$. 


\section{B. The Basis of Pincus Brothers}

\section{The Board's Failure to State Clearly its Current Deferral Standards}

The majority and concurring opinions in Pincus Brothers agreed that the Board's refusal to defer had to be overturned. One of the major rationales for this outcome was that the Board must not be permitted to change its long-standing policies without formally announcing such changes. ${ }^{67}$ Judge Rosenn stated that " $[\mathrm{i}] \mathrm{t}$ is our duty to see that the Board adheres to its established criteria unless it clearly decides to modify or alter those standards." 68 Judge Garth added that "the Board, like all agencies, is bound to adhere to the regulations and decisions it announces." ${ }^{\circ 9}$ Judges Rosenn and Garth do not object, then, to the fact that the Board has made changes over the years in its deferral policy; ${ }^{70}$ rather, their concern stems from the method by which those changes presently are being made. In Pincus Brothers, the NLRB claimed to have applied the Spielberg ${ }^{71}$ standards, yet it acted in a manner that the court found inconsistent with those standards. The Board, concluding that the award was "clearly repugnant" to the Act, refused to defer, while the majority and concurring judges concluded that the award could be interpreted as complying with the Act.

The Pincus Brothers court exacted compliance with the Spielberg requirements by the use of its standard of appellate review: 72

67 Id. 372, 379-80. Both Judges Rosenn and Garth based this view in part on two appellate decisions. In Hawaiian Hauling Service, Ltd. v. NLRB, $\mathbf{5 4 5}$ F.2d 674 (9th Cir.), cert. denied, 431 U.S. 965 (1976), the court stated:

The Board has established criteria to guide its decision and to this extent self-imposed restraints limit its discretion. In reviewing the Board, we must insure that it adheres to its own standards until they are properly changed by the Board. We will not deny enforcement unless the Board clearly departs from its own standards or its standards are themselves invalid.

Id. 676. In NLRB v. Horn \& Hardart Co., 439 F.2d 674, 679 (2d Cir. 1971), the court commented that once the Board "announce[s] a policy regarding deference to arbitration, [it cannot] blithely ignore it, thereby leading astray litigants who depended on it." See also St. Luke's Memorial Hosp., Inc. v. NLRB, 104 L.R.R.M. 2788, 2792 (5th Cir. May 21, 1980) (cautioning that the NLRB is not "Free to flout its own procedures").

68620 F.2d at 372.

69 Id. 379 (emphasis in original).

7o Indeed, Judge Garth commented that the Board is entitled to exercise discretion in formulating deferral policy and that it "appears to change its policies on deference with some regularity." Id. 380,380 n.4.

71 See text accompanying note 22 supra.

72 Recent court of appeals opinions in other circuits have required that the Board follow the Spielberg standards in determining whether it should defer. See District 1199E, Nat'l Union of Hosp. Employees v. NLRB, 613 F.2d 1102 (D.C. Cir. 1979) (case remanded to Board to insure that it, having refused to defer 
it held that a Board refusal to defer constitutes an abuse of discretion "where the findings of the arbitrator may arguably be characterized as not inconsistent with Board policy." 73 Such a standard makes it extremely difficult for the Board to refuse to uphold the arbitrator's decision because under it the Board would have to "rule out every arguable rationale for finding the employee's conduct unprotected" 74 before it could decide that particular conduct violated the Act.

Strict compliance with Spielberg has not been required in all of the courts of appeals. In NLRB v. Max Factor \& Co., ${ }^{75}$ the Ninth Circuit, faced with facts simliar to those in Pincus Brothers, ${ }^{76}$ recently declined to follow the Third Circuit's rigorous application of the "abuse of discretion" standard of review.77 Instead, the court recognized that the Board has "wide discretion" in its application of the Spielberg standards, and that "enforcing the Act's protection may be important enough to outweigh the interest in encouraging arbitration, even in cases in which the conduct was 'arguably unprotected." " 78

to the arbitrator's award, gave appropriate consideration to the award); Douglas Aircraft Co. v. NLRB, 609 F.2d 352, 354 (9th Cir. 1979) (overturning Board's refusal to defer, concluding that "[i]f the reasoning behind an award is susceptible of two interpretations, one permissible, and one impermissible, it is simply not true that the award was clearly repugnant to the Act"); NLRB v. Wilson Freight Co., 604 F.2d 712, 722 (1st Cir. 1979), cert. denied sub nom. Smith v. Wilson Freight Co., 445 U.S. 962 (1980) (Board refusal to defer and finding of section 8 (a) (1) violation both reversed and arbitrator's award reinstated; the Board could not, "in cavalier fashion," disregard arbitrator's award where "the record so plainly reveals an objective cause for discharge"). These decisions have led one commentator to suggest that the courts of appeals are concerned that the NLRB is not giving arbitration awards the deference that Spielberg requires. See Miller, The Board at the Tum of the Decade, [1980] 104 LAB. RaL. REP. (BNA) $329,330-31$.

73620 F.2d at 374 . See notes 51-54 supra \& accompanying text and note 60 supra.

74 NLRB v. Max Factor, 105 L.R.R.M. 2765, 2769 n.7 (9th Cir. Sept. 9, 1980). See notes 173-76 infra \& accompanying text.

75105 L.R.R.M. 2765 (9th Cir. Sept. 9, 1980).

${ }^{76}$ Max Factor involved facts almost identical to those presented in Pincus Brothers. Luisa Gratz, chief union steward at a Max Factor plant, was discharged because of alleged low productivity and insubordination. Gratz filed charges with the Board, and shortly thereafter grieved her dismissal under the collective bargaining agreement, eventually taking her grievance to arbitration. Id. 2766. An administrative law judge found that the employer's true motivations for the discharge were unlawful under sections $8(a)(1)$ and $8(a)(3)$ of the NLRA. Id. Shortly after this decision, an arbitrator held the dismissal valid under the contract. His award did not consider Gratz's statutory claims. The NLRB refused to defer to the award, reasoning that deferral "would engender a result repugnant to ... the Act," and that the arbitrator had not "passed on" the unfair labor practice aspects of the case. Id. 2767-68. The Ninth Circuit affirmed the NLRB solely on the former ground. Id. 2768 n.6.

77 Id. 2769 n.7.

78 Id. 
2. The Erroneous Application of Judicial Deference Standards to Board Deference Decisions

The Pincus Brothers court mistakenly equated the deference that courts accord an arbitrator's award with the degree of deference that the NLRB should accord such awards. Shortly after the Board's decision in Spielberg, the Supreme Court, in the Steelworkers Trilogy, ${ }^{79}$ announced a standard of judicial review of arbitration awards. The Trilogy cases represented judicial recognition of the utility of the arbitration process as a private method for resolving contract-governed labor disputes. The Court declared that the policy favoring arbitration expressed in section 203(d) of the LMRA 80 "can be effectuated only if the means chosen by the parties for settlement of their differences under a collective bargaining agreement is given full play." 81 To determine whether a party should be required to arbitrate a particular dispute,

the judicial inquiry . . must be strictly confined to the question whether the reluctant party did agree to arbitrate the grievance .... An order to arbitrate the particular grievance should not be denied unless it may be said with positive assurance that the arbitration clause is not susceptible of an interpretation that covers the asserted dispute. Doubts should be resolved in favor of coverage. ${ }^{\mathbf{} 2}$

Once an arbitration award has been rendered, "doubts" as to its validity are to be resolved in favor of affirmance. In United Steelworkers $v$. Enterprise Wheel of Car Corp., ${ }^{83}$ the final case in the Trilogy, the Court established the standard under which reviewing courts should judge an arbitration decision: it should be upheld "only so long as it draws its essence from the collective bargaining agreement. When the arbitrator's words manifest an infidelity to this obligation, courts have no choice but to refuse enforcement of the award." 84

The Trilogy standard of review should be invoked only when an arbitrator's interpretation and application of a contract provision

79 United Steelworkers v. American Mfg. Co., 363 U.S. 564 (1960); United Steelworkers v. Warrior \& Gulf Navigation Co., 363 U.S. 574 (1960); United Steelworkers v. Enterprise Wheel \& Car Corp., 363 U.S. 593 (1960).

8029 U.S.C. $\$ 173$ (d) (1976). See text accompanying note 24 supra.

81 American Mfg. Co., 363 U.S. at 566.

82 Warrior \& Gulf, 363 U.S. at 582-83 (emphasis added).

83363 U.S. 593 (1960).

$84 \mathrm{Id} .597$. 
is challenged in a court. The Supreme Court has never required that the decision of an arbitrator, "commissioned to interpret and apply the collective bargaining agreement," 85 be accorded the deference of the Trilogy standard in situations that involve arbitral interpretation of the NLRA. The arbitrator's competence has been judicially recognized only in those instances in which he interprets a contract, not in those in which he applies a statute.

Despite the existence in Pincus Brothers of both statutory and contractual issues, Judge Rosenn seemed to rely on the Trilogy's guidelines for the judicial review of contract-based arbitration awards to ascertain the standard that the court would instructthrough the "abuse of discretion" mechanism-the Board to apply in reviewing contract- and statute-based arbitration awards. Judge Rosenn announced this standard after citing and discussing Ludwig Honold Manufacturing Co. v. Fletcher, ${ }^{86}$ a Third Circuit decision that relied upon the Trilogy to hold that courts are required to uphold arbitration awards "so long as they are not in "manifest disregard' of the law." 87 Judge Rosenn's "arguably not inconsistent" formulation strongly resembles that found in Ludwig. Under both, if the Board (or a court) can possibly interpret an arbitrator's award so that it is consistent with the Act, it must be upheld. Because Ludwig is based on Enterprise Wheel of Car Corp. ${ }^{88}$ the standard announced in Pincus Brothers can be read as a misguided attempt to apply the requirements of the Trilogy to the Board's deferral policy.

The Pincus Brothers court's erroneous application of the Trilogy standards stems more from the Board's prior inability to resolve the deferral issue correctly than it does from the court's seeming inability to grasp the nature of the problem in a "statutory" rights case such as Pincus Brothers. In Spielberg, ${ }^{89}$ the Board failed to recognize at the outset that arbitration awards addressing purely contractual questions are entitled to a greater degree of deference than those also involving statutory issues, and left the courts with an incorrect guideline upon which to develop and apply their standards of review. The Board in Spielberg adopted one formulation-"clearly repugnant"-to guide its deferral decisions, regardless of the nature of the issues before the arbitrator. Judge Rosenn

85 Id.

86405 F.2d 1123 (3rd Cir. 1968).

${ }^{87}$ Id. 1128.

88363 U.S. 593 (1960). See Ludwig, 405 F.2d at 1126-28.

89112 N.I.R.B. 1080 (1955). See notes 20-32 supra \& accompanying text. 
explicitly mentioned Spielberg as part of the foundation underlying his "arguably inconsistent" standard.90 The court's decisions on review, then, are-as they should be-colored by the Board's decisions; unfortunately, those decisions in this area did not provide the courts with a proper path to follow.

\section{The Board in Retreat from the Spielberg Doctrine}

Notwithstanding the continued adherence to Spielberg by the Third Circuit ${ }^{91}$ and several other circuit courts, ${ }^{92}$ the Board has recently retreated from its policy of according a high degree of deference to arbitral decisions ${ }^{93}$ by substantially altering the nature of its deferral doctrine with regard to both arbitration awards and the arbitration process. It rarely defers to either anymore. This doctrinal shift, which has led former Board Chairman Edward Miller to speak in terms of the "memory of the now deceased Collyer doctrine, and . . . the ailing, and failing Spielberg doctrine," 94 evidences a change in the nature of the Board's relationship to the arbitrator and the arbitration process.

\section{A. Deferral Data}

A survey ${ }^{25}$ of cases decided from 1977 through $1980^{96}$ shows that, although in at least seventy-one instances the Board had the opportunity to dismiss an unfair labor practice complaint because of the existence of an arbitration award involving the same conduct, it chose to defer only thirteen times. ${ }^{97}$ When faced with the choice of either deferring to an arbitrator's decision or reviewing the case on its merits, then, the NLRB ignored the arbitrator's award about eighty-two percent of the time. The figures for 1980 indicate that

90620 F.2d at 374. One Board member has clearly stated this. See Hammermill Paper Co., 252 NLRB No. 172 at 8 (Sept. 30, 1980) (Member Penello dissenting) (equating the Spielberg standard for deferral with Judge Rosenn's application of the abuse of discretion standard).

91 NLRB v. Pincus Bros., Inc.-Maxwell, 620 F.2d 367 (3d Cir. 1980).

92 See note 72 supra.

93 See notes 95-123 \& 128-36 infra \& accompany text.

94 Miller, supra note 72 , at 329 .

95 This Comment's survey categorizes each deferral decision according to whether it is a deferral to an arbitration award (Spielberg), see text accompanying notes 20 22 supra, or to the arbitration process (Collyer), see text accompanying notes 33-38 supra. See Appendix, Tables I \& II, infra.

96 This time period was chosen because 1977 marks the beginning of the period in which the NLRB, through a series of decisions, significantly limited the Spielberg and Collyer doctrines. See text accompanying notes 104-44 infra.

97 See Appendix, Table I, infra. 
the Board is continuing the practice of ignoring arbitration awards in the great majority of cases. It considered deferral in twentythree cases, ${ }^{98}$ yet chose to defer only five times. ${ }^{99}$

The data on the declining incidence of "Collyer deferrals" to the arbitration process ${ }^{100}$ provide an even clearer illustration of the

98 See Appendix, Table I, infra.

99 Id. It is possible that the NLRB's retreat from Spielberg began before 1977. The statistics presented in Note, The NLRB and Deference to Arbitration, 77 YALE L.J. 1191 (1968), indicate that during the period 1960-1964 the Board deferred to arbitration in the unfair labor practice context $23.1 \%$ of the time (deferral in six of 26 cases). Id. 1219. During 1965-1967, however, the Board deferred to arbitration in only $11.1 \%$ of the applicable cases (deferral two of 16 times). Id. 1220. While a comparison with the combined figures for the period from 1977-1980 does not indicate a downward trend in the proportion of Board deferrals-the combined deferral rate for the latter period is about $12 \%$ (15 of 127 cases), see Appendix, Table III, infra-the value of using the Yale data for comparison purposes may well be negligible for at least two reasons.

First, the number of cases analyzed in the Yale Note was significantly lower than the number that this Comment has compiled. It is possible that the simple explanation is that many more requests for deferral have been presented to the Board in the past few years than were presented to it in the mid-sixties. It is also likely, however, that many cases were missed in the Yale survey because of the deficient indexes provided by the NLRB at that time. The author of the Note acknowledged this problem, which made "difficult an accurate and complete classification of Board cases involving the possibility of deference to arbitration." Note, supra, at 1219. The author also pointed to another such factor: "the Board has, all too often, failed to state its reasoning with sufficient clarity to enable the commentator to determine with confidence what, if any, weight is being given to the existence, or possibility, of an arbitration award." Id. These factors detracting from the earlier analysis-although present in this Comment's surveyhave probably not created a significant problem here, because better indexing, computer scanning for key words (through Lexis), and more precise references to the existence of an arbitration award have made it much easier to identify almost all cases involving the possibility of deferral.

Another potential explanation for the static proportion of deferrals is that there might have been an upswing in the number of deferrals granted after 1965, which began to taper off around 1977. If the figure in the Yale Note is reasonably accurate, the NLRB has seen a dramatic increase in the number of cases in which deferral is at issue since the 1965-1967 time period-from about three to 30 cases per year. Although this increase may have resulted from forces other than those created by the Board itself, it seems likely that Board decisions of the early $1970 \mathrm{~s}$ contributed to the increased demand for deferrals. The holdings in Collyer, see text accompanying notes 33-38 supra, and Electronic Reproduction Service Corp., see text accompanying notes 133-36 infra, formally announced the Board's increasingly favorable doctrinal slant toward deferral. Thus, it seems possible that, although the Board announced its Spielberg standards in 1955, the Board did not begin to favor significant use of the doctrine until the late 1960s, and deliberately began to curtail its significance around 1977. See text accompanying notes 104-32 \& 139-44 infra. Unfortunately, this Comment is unable to cite any studies that contain the data either to confirm or refute empirically this description of evolving Board attitudes toward arbitral deferral. The reader is left with only two reasonably substantiated points to gather from this discussion: the Board's decisions in the last few years appear as if they were designed to decrease the number of deferrals from their pre-1977 levels, and statistics from the most recent time period confirm that today the Board rarely defers to either an arbitration award or the arbitration process.

100 Collyer Insulated Wire, A Gulf \& Western Systems Co., 192 N.L.R.B. 837 (1971); see text accompanying notes 33-38 supra. 
Board's recent attitude toward deferral. From 1977 through 1980 the Board considered deferring an unfair labor practice complaint to a contractual arbitration procedure fifty-six times; ${ }^{101}$ it granted deferral on only two occasions, both in 1977.102 Since the beginning of 1978, it has refused to remand, under Collyer, a complaint to an arbitrator in thirty-three consecutive cases. ${ }^{103}$

\section{B. Legal Milestones in the Board's Retreat}

Several recent NLRB decisions have significantly limited the reach of both Spielberg ${ }^{104}$ and Collyer. ${ }^{105}$ The Board's decision in General American Transportation Corp. ${ }^{106}$ resulted in a sizable cutback in the number of Board deferrals to the arbitration process. The case involved an employee's claim that he had been discharged for engaging in protected activity. The employer sought deference to the contract remedy of arbitration, but the Board refused to authorize a Collyer deferral.107 While Members Fanning, Jenkins, and Chairman Murphy all refused to defer, the analysis presented in the Chairman's concurring opinion ${ }^{108}$ had the greatest influence on subsequent cases. ${ }^{109}$

The Chairman distinguished disputes involving differences as to the interpretation of a provision of a collective bargaining agreement, ${ }^{110}$ which should be determined by an arbitrator, ${ }^{111}$ from disputes involving employer interference with section 7 employee rights, ${ }^{112}$ which cannot be resolved conclusively through arbitration. ${ }^{113}$ As stated by the Chairman, an employee's section 7 rights

101 See Appendix, Table II, infra.

$102 I d$.

$103 \mathrm{Id}$.

104 Spielberg Mfg. Co., 112 N.L.R.B. 1080 (1955).

105192 N.L.R.B. 837 (1971).

108228 N.L.R.B. 808 (1977).

107 Id.

108 Id. 810.

109 See note 115 infra \& accompanying text.

110228 N.L.R.B. at 810 (Chairman Murphy concurring). She called these contractual disputes "private rights" disputes, and defined private rights as "[r]ights under a collective bargaining agreement ... [that are] created by contract and enforceable under procedures established by the contract for that purpose ...." Id. 813.

111 Id. 810-11. The principal issue in these cases is usually whether certain conduct is in derogation of the complainant's contractual rights. "Such suits are eminently suited to the arbitral process ....." Id. 810 .

112 NLRA $\$ 7,29$ U.S.C. $\$ 157$ (1976). See note 9 supra.

113 The Chairman referred to $\$ 7$ disputes as "public rights" controversies. 228 N.L.R.B. at 813 (Chairman Murphy concurring). 
"must be protected by the Board in its public capacity of giving effect to the declared public policy of the Act." 114

This position has been adopted by the Board in other cases holding that complaints alleging interference with employee section 7 rights may not be deferred to the arbitration process. ${ }^{115}$ Although Chairman Murphy indicated that, where arbitration had been entered into voluntarily by all parties, existing arbitration awards being reviewed under Spielberg would not be affected by the General American decision, ${ }^{116}$ the Board has since failed to clearly resolve the question. It appears, however, that Spielberg is not affected.117

The Spielberg "repugnancy" standard, previously interpreted by the Board as requiring deferral to an award unless it is "palpably wrong," 118 was substantially altered by its decision in The Kansas City Star Co.119 Member Truesdale's concurring opinion states that, in analyzing an award, the Board majority correctly examined "the arbitrator's legal conclusion to see if, on the facts he has found, it is consistent with Board law." ${ }^{120}$ In a later case, ${ }^{121}$ Member Truesdale further explained this view of the repugnancy requirement, stating that when "the arbitrator's legal conclusions are not consistent with Board law . . . [they] are repugnant to the Act." 122 Requiring an arbitration award to be "consistent with Board law"

114 Id.

115 See, e.g., Caterpillar Tractor Co., 250 N.L.R.B. No. 89 (July 10, 1980); Container Corp. of America, 244 N.L.R.B. No. 53 (August 17, 1979); Ackerman Mfg. Co., 241 N.L.R.B. No. 106 (March 30, 1979).

110228 N.L.R.B. at 812-13 (Chairman Murphy concurring).

117 Compare Servair, Inc., 236 N.L.R.B. 1278, 1278 n.1 (1978), rev'd, 102 L.R.R.M. 2705 (9th Cir. 1979), petition for reh. granted, No. 78-2791 (9th Cir. 1980), opinion withdrawn and remanded, 624 F.2d 92 (9th Cir. 1980) ("we find it unnecessary to determine, in these circumstances, whether our decision in Spielberg .... is in any way affected by our recent decision in General American Transportation Corporation") with Gould, Inc. (Switchgear Div.), 238 N.L.R.B. No. 88 at 2, enforced, 105 L.R.R.M. 2788 (10th Cir. Oct. 7, 1980) (the Board, in the course of refusing to defer to an arbitration award, states that this decision does "not rely on General American Transportation Corporation ....., inasmuch as the arbitrator's award has already issued in this case"), and NLRB v. Max Factor \& Co., 105 L.R.R.M. 2765, 2767 (9th Cir. Sept. 9, 1980) ("[a]lthough a majority of the Board has rejected the Collyer policy of deferral to prospective arbitration, at least as applied to individual rights cases under Sections 8(a)(1) and (3), see General Am. Transp. Company [sic] . . . the Spielberg policy appears to remain in effect") (footnotes omitted).

118 International Harvester Co., 138 N.L.R.B. 923, 929 (1982), enforced sub nom. Ramsey v. NLRB, 327 F.2d 784 (7th Cir.), cert. denied, 377 U.S. 1003 (1964).

119236 N.L.R.B. 866 (1978).

120 Id. 869 (emphasis added).

121 Sea-Land Serv., Inc., 240 N.L.R.B. 1146 (1979).

${ }_{122}$ Id. 12 n.8 (Member Truesdale concurring). 
accords the award considerably less deference than would be the case if the award needed only to meet the Spielberg "clearly repugnant" test before becoming final. ${ }^{123}$ The "consistent with Board law" approach ${ }^{124}$ enables the NLRB to substitute its decision for that of the arbitrator ${ }^{125}$ when the Board disagrees with the arbitrator.

Member Penello has been unwilling to accept this dilution of the repugnancy requirement and, in a series of dissenting opinions, has presented his view that the Board's current application of the Spielberg doctrine is unfaithful to the case law in the area and is unwise from a policy standpoint. ${ }^{128}$ For example, he has asserted that members of the Board majority

defer to an arbitration award only when they happen to agree with the arbitrator's decision. This pretended application of the Spielberg doctrine effectively serves to oust arbitrators of any real authority to issue final adjudications to disputes over provisions in collective-bargaining agreements, since my colleagues in the majority have now assumed for themselves the role of final arbiter for the parties over such matters. Thus, it is readily apparent that the majority seeks to change the third Spielberg criteria from "merely [sic] repugnant" to "merely erroneous," thereby substituting their judgment for that of an arbitrator. ${ }^{127}$

${ }^{123} \mathrm{Id}$. 18 (Member Penello dissenting) (stating that Member Truesdale's "consistency standard [is a] much looser standard then the Spielberg "clearly repugnant' test.").

124 Although the NLRB has never explicitly overruled the repugnancy standard, the finding that an arbitration award was inconsistent with Board law has been accepted by the Board as a sufficient basis for a refusal to defer. See Atlantic Steel Co., 245 N.L.R.B. No. 107 at 5 (Sept. 28, 1979), in which the Board based its decision to defer on Kansas City Star.

125 See text accompanying note 128 infra.

126 Hammermill Paper Co., 252 N.L.R.B. No. 172 at 7 (Sept. 30, 1980) (Member Penello dissenting); Babcock \& Wilcox, 249 N.L.R.B. No. 99 at 10-11 n.9 (May 23, 1980) (Member Penello dissenting); Brown Co., 101 L.R.R.M. 1608, 1611 (NLRB July 30, 1979) (Members Penello and Murphy dissenting); Sea-Iand Serv., Inc., 240 N.L.R.B. 1146, 1152 (1979) (Member Penello dissenting); Douglas Aircraft Co., 234 N.L.R.B. 578, 581 (1978) (Member Penello dissenting), rev'd, 609 F.2d 352 (9th Cir. 1979); Clara Barton Terrace Convalescent Center, 225 N.L.R.B. 1028, 1031-32 (1976) (Members Penello and Walther dissenting); Hawaiian Hauling Service, Ltd., 219 N.L.R.B. 765, 767 (1975) (Members Penello and Kennedy dissenting), enforced, 545 F.2d 674 (9th Cir.), cert. denied, 431 U.S. 965 (1976).

127 Sea-Land Service, Inc., 240 N.L.R.B. 1146, 1151 (1979). Member Penello reminded the majority that under a "clearly repugnant" standard a Member should be bound to accept an award that is not clearly repugnant, even if the Member would otherwise disagree with it. Id. 1151 n.I9. 
The latest step in the Board's narrowing of the deferral doctrine came in the recent case of Suburban Motor Freight, Inc., ${ }^{128}$ in which the NLRB held that when an employee contends that his discipline and/or discharge violated the Act, ${ }^{129}$ the Board will not defer to "an arbitration award [upholding the employer's action under the contract] which bears no indication that the arbitrator ruled on the statutory issue of discrimination in determining the propriety of an employer's disciplinary actions." 130 The NLRB will "no longer honor the results of an arbitration proceeding under Spielberg unless the unfair labor practice issue before the Board was both presented to and considered by the arbitrator." 131 Under this formulation, the party seeking Board deferral to an arbitration award has the burden of proving that all potential statutory issues were adequately considered by the arbitrator..$^{132}$

An earlier decision, Electronic Reproduction Service Corp. ${ }^{133}$ established that the Board would presume that the statutory issues implicated in a discipline or discharge case had been presented to, and decided by, the arbitrator "except when unusual circumstances are shown which demonstrate that there were bona fide reasons . . . which caused the failure to introduce such evidence at the arbitration proceeding." 134 Suburban Motor Freight reversed the Elec-

128103 L.R.R.M. 1113 (NLRB Jan. 8, 1980).

129 Violations of sections $8(\mathrm{a})(1)$ and (3) of the Act were alleged. Id. 1114. See notes 6-13 supra \& accompanying text.

130103 L.R.R.M. at 1114.

131 Id. The effect of the presentation and consideration requirements is that the Board "will give no deference to an arbitration award which bears no indication that the arbitrator ruled on the statutory issue. ..." Id. For an example of how these requirements have been applied, see General Warehouse Corp., 247 N.L.R.B. No. 142 (Feb. 14, 1980), in which the Board refused to defer to an arbitration award that had upheld a discharge, on the grounds that the arbitrator did not consider evidence relevant to the protected activities engaged in by the employee and the relationship of those activities to his termination. See also Kahn's \& Co., Div. of Consol. Food Co., 253 N.L.R.B. No. 4, (October 10, 1980); Sachs Elec. Co., 248 N.L.R.B. 669 (1980).

132 Suburban Motor Freight, 103 L.R.R.M. at 1114.

133213 N.L.R.B. 758 (1974). that

$134 \mathrm{Id} .762$ (footnote omitted). The basis of this rule was the Board's belief

the usual and normal practice of parties to collective agreements is to submit to the arbitrator the central issue of the justness or unjustness of the discipline or discharge and that it is the normal practice of the parties to submit, and of arbitrators to consider as relevant ... evidence of unfairness or unjustness arising out of antiunion discrimination of the type which we consider in cases arising under Section 8(a)(3) of our Act. 
tronic Reproduction rule ${ }^{\mathbf{1 3 5}}$ and narrowed the circumstances under which the Board will defer to an arbitration award. ${ }^{136}$

The Suburban Motor Freight rule readjusts the erroneous balance created in Electronic Reproduction between the statutory mandates of section 203(d) of the LMRA ${ }^{137}$ and section 10(a) of the NLRA.138 The Board explained that its deferral policy had to be reevaluated in light of recent "experience":

Our experience with Electronic Reproduction has led to the conclusion that it promotes the statutory purpose of encouraging collective-bargaining relationships, but derogates the equally important purpose of protecting employees in the exercise of their rights under Section 7 of the Act. ...

The Board can no longer adhere to a doctrine which forces employees in arbitration proceeding [sic] to seek simultaneous vindication of private contractual rights and public statutory rights, or risk waiving the latter..$^{139}$

In making this readjustment between the two statutory provisions, Suburban Motor Freight essentially reinstated what had been the Board's deferral policy prior to Electronic Reproduction. In Raytheon Co., ${ }^{140}$ a 1963 decision, the Board refused to defer to an arbitration award upholding a discharge because "the arbitrator necessarily [as a result of the complainant's pleadings] addressed himself, in making his award, solely to the contractual issue litigated before him. . . . [H] necessarily ignored the unfair labor practice now in issue before the Board." 141 In 1972, the Board formally announced that no deference would be given to an arbitration award bearing no indication that the statutory issues had been con-

135 Suburban Motor Freight, 103 L.R.R.M. at 1114.

The Electronic Reproduction rule had been severely criticized in both judicial opinions and scholarly literature prior to its demise in the Suburban Motor Freight decision. See, e.g., Stephenson v. NLRB, 550 F.2d 535 (9th Cir. 1977); Schatzki, Majority Rule, Exclusive Representation, and the Interests of Individual Workers: Should Exclusivity Be Abolished?, 123 U. PA. L. REv. 897, 909 n.32 (1975); Simon-Rose, Deferral Under Collyer by the NLRB of Section 8(a)(3) Cases, 27 LAB. L.J. 201, 209-12 (1976); 11 Lox. L.A.L. REv. 199, 220-22 (1977).

136 Miller, supra note 72 , at 330 .

13729 U.S.C. $\$ 173(\mathrm{~d})$ (1976). See text accompanying note 24 stura. 13829 U.S.C. $\oint I 60$ (a) (1976). See text accompanying note 23 supra. The Board did not have to balance these two provisions at all, but has done so ever since Spielberg. See text accompanying notes 23-27 supra.

139 Suburban Motor Freight, 103 L.R.R.M. at 1114.

140140 N.L.R.B. 883 (1963), enforcement denied on other grounds, 326 F.2d 471 (1st Cir. 1964).

141 Id. 884-86. 
sidered ${ }^{142}$ and that the burden to prove such consideration would be on the party seeking deferral. ${ }^{143}$ Electronic Reproduction, then, can be seen as an aberration from the Board's traditional policy of trying to ensure adequate consideration of all unfair labor practice claims. ${ }^{144}$

\section{C. "Adoption" of Arbitral Decisions}

The Board's return to its policy of requiring proof of an arbitrator's consideration of statutory issues may have been inspired by the Supreme Court's opinion in Alexander $v$. Gardner-Denver Co. ${ }^{145}$ Gardner-Denver held that an employee's Title VII-based challenge to his discharge, ${ }^{146}$ brought in federal district court, could not be dismissed despite previous consideration of the claim in an arbitration proceeding conducted in accordance with the applicable collective-bargaining agreement. ${ }^{\mathbf{1 4 7}}$ The Board's analysis of the deferral-to-arbitration doctrine in Suburban Motor Freight is similar to the Supreme Court's analysis of the issues in this Title VII case.

The basis of the Court's decision is that the discharge of an employee gives rise to issues surrounding both statutory and contractual rights. These rights are deemed independent of one another; the determination of the contractual right by the arbitrator does not foreclose federal district court consideration of the statutory claim because the two rights spring from different sources-the collective bargaining agreement as opposed to a federal statute. ${ }^{148}$ The Court analogized this distinction to the roles played by an

142 Airco Industrial Gases-Pacific, A Division of Air Reduction Co., 195 N.L.R.B. 676 (1972).

143 Yourga Trucking, Inc., 197 N.L.R.B. 928 (1972).

144 Several recent appellate decisions also support the Board's current view that deferral is inappropriate absent evidence that the arbitrator has satisfactorily decided the statutory issues. See, e.g., Stephenson v. NLRB, 550 F.2d 535, 539 (9th Cir. 1977) ("the Board cannot abdicate its duty to consider unfair labor practice charges by deferring when it has no lawful or reasonable basis for doing so"); Banyard v. NLRB, 505 F.2d 342, 347 (D.C. Cir. 1974) (NLRB deferral to an arbitral tribunal will be upheld only if the tribunal " $(A)$ clearly decided the issue on which it is later urged that the Board should give deference, and

(B) the arbitral tribunal decided an issue within its competence.").

145415 U.S. 36 (1974).

146 Title VII of the Civil Rights Act of 1964,42 U.S.C. $\$ \$ 2000 \mathrm{e}-2000 \mathrm{e}-17$ (1976 \& Supp. II 1978). The employee in Gardner-Denver claimed that his discharge was the result of racial discrimination.

147415 U.S. at $42-43$.

148 The Supreme Court stated that "a contractual right to submit a claim to arbitration is not displaced simply because Congress also has provided a statutory right against discrimination. Both rights have legally independent origins and are equally available to the aggrieved employee." Id. $\mathbf{5 2}$. 
arbitrator and the NLRB in the adjudication of a grievance that includes a statutory question:

The resulting scheme is somewhat analogous to the procedure under the National Labor Relations Act, as amended, where disputed transactions may implicate both contractual and statutory rights. Where the statutory right underlying a particular claim may not be abridged by contractual agreement, the Court has recognized that consideration of the claim by the arbitrator as a contractual dispute under the collective-bargaining agreement does not preclude subsequent consideration of the claim by the National Labor Relations Board as an unfair labor practice charge . . . . There, as here, the relationship between the forums is complementary since consideration of the claim by both forums may promote the policies underlying each. ${ }^{148}$

At least one judicial opinion, ${ }^{150}$ a Board decision, ${ }^{151}$ and a plethora of law review articles 152 have discussed whether the Gardner-Denver decision, arising under Title VII, should be applied to the NLRB's deferral policy. In Suburban Motor Freight, the Board appears to have implicitly resolved the issue in favor of its application because, after that decision, it appears that a discharge for "just cause" ${ }^{153}$ will not foreclose NLRB adjudication of a subsequent claim that the discharge violated the Act, unless either of two conditions are met. First, if the facts as found by the arbitrator and reviewed by the General Counsel show that the case does not involve an unfair labor practice, ${ }^{154}$ the General Counsel will not issue a complaint. ${ }^{155}$ In this situation, the contractual right ("just cause") has been determined by the arbitrator-the Board has

149 Id. 50-51 (footnotes \& citations omitted).

150 Stephenson v. NLRB, 550 F.2d 535, 538 n.4, 539 (9th Cir. 1977).

151 Electronic Reproduction Service Corp., 213 N.L.R.B. 758, 762-64 (1974). 152 See, e.g., Getman, Can Collyer and Gardner-Denver Co. Co-Exist? A Postscript, 49 IND. L.J. 285 (1974) (Gardner-Denver is applicable); Nash, Board Referral to Arbitration and Alexander v. Gardner-Denver: Some Preliminary Observations, 25 LAB. L.J. 259 (1974) (Gardner-Denver is not applicable); SimonRose, supra note 135 (background discussion of issues involved); Note, Alexander v. Gardner-Denver and Deferral to Labor Arbitration, 27 Hastungs L.J. 403, 425 (1975) (Gardner-Denver is not applicable); Note, NLRB Deferral of Section $8(a)(5)$ Refusal to Bargain Cases to Arbitration, 20 ST. Lours U. L.J. 489, 503-06 (1976) (Gardner-Denver is applicable); 88 HaRv. L. Rev. 804, 809-11 (1975) (Gardner-Denver is applicable).

153 See note 3 supra.

154 For example, a case in which an employee was fired for wholly legitimate reasons, such as low productivity, high absenteeism, or poor work quality.

155 On the General Counsel's role, see note 62 supra. 
no authority to review this issue-156 and the General Counsel has decided that no statutory issue exists. Second, the NLRB will dismiss the case if the arbitrator has been presented with and considered the unfair labor practice issue and has resolved it in a manner consistent with the way in which the Board would have decided such a question. ${ }^{157}$ The Board no longer grants the type of deference contemplated in Spielberg, under which arbitration decisions foreclose subsequent Board adjudication unless they are "clearly repugnant" to the policies of the NLRA implicated by the underlying conduct being complained of.

Rather, it shows real deference to an arbitrator only in the type of situation envisioned by the Supreme Court in Gardner-Denver for district court deferral to arbitration: where the arbitrator is competent to decide the issues for which deference is being sought. ${ }^{158}$ Because an arbitrator is not empowered by statute to enforce the important statutory rights stemming from the NLRA-just as he cannot enforce Title VII rights-the Board will defer to his decision involving statutory rights only when it agrees with the decision.

This new policy places the arbitration award in a very different role than the one it played under the original Spielberg formulation. By deciding that it will defer to an arbitration award only when "the award is in accord with the Act and Board precedent," 159 the Board is demonstrating that the arbitrator is not a substitute for itself, but is instead more akin to an "unofficial administrative law judge," ${ }^{160}$ whose decisions the Board is not bound to accept. When the Board does defer to an arbitration award, it is "adopting" the arbitrator's conclusion as its own, rather than deferring to his judgment. ${ }^{161}$ In effect, the NLRB is deciding unfair labor practice complaints through the medium of an arbitration award.

\section{The Question of Judicial Review: Pincus Brothers}

The standard used by the Pincus Brothers ${ }^{162}$ court for the review of Board refusals to defer to arbitration awards-that the

156 The NLRA gives no affirmative authority to the Board over purely contractual disputes, and the LMRA encourages the resolution of such disputes through arbitration whenever possible. See text accompanying notes 23 \& 24 supra.

${ }^{157}$ See notes 119-25 supra \& accompanying text.

158415 U.S. at 53-54.

159 Atlantic Steel Co., 245 N.I.R.B. No. 107 at 13 (Sept. 28, 1979) (Member Penello concurring).

160 Id. See note 47 supra.

161245 N.L.R.B. No. 107 at 13 (Member Penello concurring).

182 NLRB v. Pincus Bros., Inc.-Maxwell, 620 F.2d 367 (3d Cir. 1980). 
Board's decision not to defer will be overturned as an abuse of discretion if the award is "arguably . . . not inconsistent with Board policy"-163 requires that the NLRB follow its deferral policy as announced in Spielberg. ${ }^{164}$ Under the Pincus Brothers standard, the Board will be hard-pressed in the Third Circuit to justify its refusals to defer. ${ }^{165}$

One root of the Third Circuit's reluctance to allow the Board to abandon deferral in the Spielberg tradition is the "national policy in favor of labor arbitration." 160 Arbitration has been praised by both Congress ${ }^{107}$ and the Supreme Court. ${ }^{168}$ Commentators have pointed out that it allows for the settlement of disputes efficiently, non-violently, and without the invention of any governmental body. ${ }^{109}$ When operating within its sphere of competency, it achieves the goals for which all systems of dispute resolution strive: finality, neutrality, guidance, and obedience. ${ }^{170}$

Although the voluntary adjustment of contractual labor disputes is a worthwhile objective for the Board and courts to pursue, the Board has a right and, indeed, a responsibility to adjudicate statutory disputes. ${ }^{17 I}$ In Spielberg, the Board mistakenly endorsed the policy of allowing private tribunals to decide issues involving statutory rights so long as the resulting awards were not "clearly repugnant" to the Act; recent Board decisions recognize the dangers in not taking a more active role in reviewing arbitral decisions affecting statutory rights. ${ }^{172}$ In NLRB $v$. Max Factor \& Co., ${ }^{173}$ the

163 Id. 374.

$16 \pm$ Spielberg Mfg. Co., 112 N.L.R.B. 1080 (1955). See notes 20-32 supra \& accompanying text.

${ }^{165}$ See NLRB v. Max Factor \& Co., 105 L.R.R.M. 2765, 2769 n.7 (9th Cir. Sept. 9, 1980). text.

166 Pincus Brothers, 620 F.2d at 374. See notes 39-88 supra \& accompanying

167 See LMRA § 203(d), 29 U.S.C. $\$ 173(d)$ (1976). See text accompanying note 24 supra.

168 See, e.g., Carey v. Westinghouse Corp., 375 U.S. 261, 272 (1964) (referring to the "therapy of arbitration"); United Steelworkers v. Warrior \& Gulf Navigation Co., 363 U.S. 574, 582 (1960) (discussing the arbitrator's special "competence" for determining contractual grievances); United Steelworkers v. Enterprise Wheel \& Car Corp., 363 U.S. 593, 596 (1960) (labelling arbitrators "indispensable agencies in a continuous collective bargaining process").

109 See, e.g., F. Erkourx \& E. Elkourr, How Arbitration Works 8-10 (3rd ed. 1974); Hepburn \& Loiseaux, The Nature of the Arbitration Process, 10 VAND. L. REv. 657 (1957).

170 See Getman, Labor Arbitration and Dispute Resolution, 88 YALE L.J. 916 (1979). The value of the arbitration process, however, is not universally accepted. See P. Hays, Labor Arbitration: A Drssenting VIew (1966).

171 See notes 6-13 \& 23-27 supra \& accompanying text.

172 See notes 137-43 supra \& accompanying text.

173105 L.R.R.M. 2765 (9th Cir. Sept. 9, 1980). 
Ninth Circuit expressly repudiated the Pincus Brothers standard 174 and sanctioned a more active role for the Board. Under the Ninth Circuit's approach, if the Board finds that the arbitrator's result is not "appropriate under the Act," and that "the interest in affording the Act's protection is so compelling under the circumstances that it outweighs the interest in encouraging private resolution of disputes through arbitration," the Board may refuse to defer on the ground that the award is "clearly repugnant to the Act." 175

The importance of a court giving the NLRB the flexibility to refuse to defer to an award that is only "inconsistent" with the policies of the NLRA cannot be understated. A strict application of the deferral policies enunciated in Spielberg, as extended by Electronic Reproduction, ${ }^{176}$ reduces the statutory protections of employees and employers because it leaves the determination of statutory rights to a private arbitral tribunal devoid of public policy responsibilities. Unlike the private arbitrator, the Board is required to serve the public interest. ${ }^{177}$ The Second Circuit, in

174 Id. 2769 n.7. See text accompanying notes 75-78 supra.

175105 L.R.R.M. at 2769.

While the Max Factor decision does give the NLRB a degree of needed flexibility in deciding how to treat an arbitration award, it should be noted that the Ninth Circuit has made some of the same analytic errors that have characterized court and NLRB decisions in this area. First, the court perceived a statutory conflict where none exists. The court incorrectly stated that, in order to resolve the issue of when the Board should defer to an arbitration award, the court must reconcile "two important policies which are in tension: the policy favoring the exercise of jurisdiction by the Board to prevent unfair labor practices and the policy favoring the "settling of labor disputes by arbitration." 105 L.R.R.M. at 2767 (quoting United Steelworkers v. Enterprise Wheel \& Car Corp., 363 U.S. 593, 596 (1960)). These two policies, however, are complementary, and any tension between them is imaginary. See notes 23-26 \& $145-49$ supra \& accompanying text.

Second, the Max Factor court adopted a very uncertain guideline for determining when deference is appropriate: when "the interest in affording the Act's protection is so compelling under the circumstances that it outweighs the interest in encouraging private resolution of disputes through arbitration." Id. 2769. That formulation, which the Board is supposed to be able to use in deciding the large number of deferral cases brought before it each year, is even more ambiguous than the "clearly repugnant" standard. The Max Factor standard requires a balancing of interests, but provides no guidance on how to go about that balancing. The Board's current deferral practice utilizes a more definitive standard: it is based on a comparison of the arbitrator's treatment of the relevant statutory questions with the NLRB's history of dealing with those questions. See notes 10444 supra \& accompanying text.

176 Electronic Reproduction Service Corp., 213 N.L.R.B. 758 (1974). See notes 133-39 supra \& accompanying text. Prior to Max Factor, the Ninth Circuit had rejected the deferral practice established in Electronic Reproduction "as it permits the Board to base its deference upon mere presumption in total absence of any evidence." Stephenson v. NLRB, 550 F.2d 535, 541 (9th Cir. 1977).

177 NLRA $\$ I(b), 29$ U.S.C. $\$ I 41$ (b) (1976), provides in part: "It is the purpose and policy of this chapter . . . to protect the rights of the public in connection with labor disputes affecting commerce." 
$N L R B$ v. Horn \& Hardart Co., ${ }^{178}$ has examined this functional difference between the NLRB and arbitrators:

The National Labor Relations Act guarantees certain rights to employees, employers . . . and the public, and the Board is charged with protecting these interests. An arbitrator is not. His function is to discern the intention of the parties to a contract, who have hired him to resolve their differences. The interests of third parties, such as an individual employee, a group of employees or the public, are not his primary concern. ${ }^{179}$

Cognizant of these concerns, the Board's present deferral policy correctly requires that the arbitrator decide the statutory issues in the case in a manner consistent with Board precedent on those issues. ${ }^{180}$ Given the nature of the Board's statutory responsibility, the standard established in Pincus Brothers for review of NLRB refusals to defer to arbitration awards is inappropriate.

\section{Proposals For The Future}

Consistent with its statutory mandate, the Board has restricted its support of arbitration awards by limiting the circumstances under which it will defer to them. The Pincus Brothers ${ }^{181}$ panel sought to inhibit this trend by applying the traditional "abuse of discretion" standard of review in a way that virtually requires the NLRB to dismiss complaints implicating conduct that has been the subject of a prior arbitration award. This application should be modified, because it results in the loss of a considerable degree of Board protection of NLRA rights. However, this shift in the appellate review of Board deferred decisions should be presaged by

178439 F.2d 674 (2d Gir. 1971). The Second Circuit upheld in this case an NLRB refusal to defer.

179 Id. 678. This view has been stated even more strongly by Members Fanning and Jenkins, concurring in Electronic Reproduction Service Corp.:

Arbitration is essentially alien to determination of public rights. Arbitrators have no expertise in the interpretation of the Act. The Board does. The arbitrator is bound to give effect to the collective-bargaining agreement, whatever might be its inconsistency with the law. And public rights cannot be left unvindicated, if the Act is to afford equal protection and uniform application.

213 N.I.R.B. 758, 765 (1974). See also Stephenson v. NLRB, 550 F.2d 535, 539 n.6 (9th Cir. 1977). Cf. Alexander v. Gardner-Denver Co., 415 U.S. 36, 57 (1974) (comparison of the relative abilities of an arbitrator and a federal district court to decide statutory questions arising under Title VII).

180 See notes $119-44$ supra \& accompanying text.

181 NLRB v. Pincus Bros., Inc.-Maxwell, 620 F.2d 367 (3d Cir. 1980). 
a change in the way that the Board itself formally defines ${ }^{182}$ its policy on arbitration awards adjudging conduct that is claimed to. violate the NLRA. ${ }^{188}$

\section{A. The National Labor Relations Board}

Recently, the Board has implicitly redefined the concepts of "deferral" and "repugnancy." 184 Unless it now clearly articulates those changes, reviewing courts cannot be expected to adopt more responsive standards of review. 185 The impetus for this "announcement" must come from the Board itself, because the courts of appeals have traditionally been unsuccessful in forcing the Board to clarify its policies when they appear inconsistent with past Board precedent. ${ }^{186}$

The policy shift that this Comment suggests the Board formally announce is substantial. Although the NLRB has been claiming. to follow a policy of deferral to arbitration for over twenty-five years, ${ }^{187}$ deferral presently bears only a remote resemblance to deferral in years past. The Board should explicitly state that it will now defer to an award only when the arbitrator has considered all statutory issues involved and has resolved them the same way that the Board would have had it heard the case de novo. An arbitrator's award is no longer given deference when it is a plausible

182 The Board has never formally overruled any of the Spielberg criteria, so. it has not actually admitted that it is modifying the "clearly repugnant" standard. One must look to the practical effects of its decisions and Member Truesdale's concurring opinions. See notes 118-22 supra \& accompanying text.

$183 \mathrm{It}$ is well-settled that, apart from formal rulemaking proceedings, the Board can adopt or revise policies while engaged in the process of adjudication. See NLRB v. Bell Aerospace Co., 416 U.S. 267, 290-95 (1974); NLRB v. WymanGordon Co., 394 U.S. 759, 765-66 (1969). Cf. Shapiro, The Choice of Rulemaking or Adjudication in the Development of Administrative Policy, 78 HARv. L. REv. 921, 947-52 (1965) (suggesting that decisionmaking may believe that their agency is freer to depart from prior policies established through adjudication than from policies established through formal rulemaking).

184 See text accompanying notes 119-61 supra.

${ }^{185}$ As discussed above, however, see text accompanying notes 173-75 supra, the Ninth Circuit has adopted a more flexible stance in spite of the NLRB's unwillingness to articulate its current policy. NLRB v. Max Factor \& Co., 105 L.R.R.M. 2765 (9th Cir. Sept. 9, 1980).

186 An example of the inability of the courts to force NLRB policy clarifications is provided by the subsequent history of NLRB v. International Longshoremen's Local 50, 504 F.2d 1209 (9th Cir. 1974), cert. denied, 420 U.S. 973 (1975). There, the court sought to require the Board to clarify its principles in the confused area of work jurisdictional disputes under $\S 10(\mathrm{k})$ of the Act, 29 U.S.C. $\$ 160(k)$ (1976). The NLRB flatly refused to obey the court's directive. See International Longshoremen's Local 50, 223 N.L.R.B. 1034 (1976).

187 Spielberg, 112 N.L.R.B. 1080 (1955), was decided on June 8, 1955. 
result-it must be the Board's result. This policy is more akin to the "adoption" of arbitral decisions than it is to arbitral deferral, and this distinction should be made clear by the Board.

The NLRB did present portions of this analysis in Suburban Motor Freight, ${ }^{189}$ but its statements on deferral did not go far enough. Although the Board stated that it would "no longer honor the results of an arbitration proceeding under Spielberg unless the unfair labor practice issue was both presented to and considered by the arbitrator," 100 it should also have stated the conditions under which it would affirm the arbitration results. As stated above, to accurately define its new deferral practice, the NLRB should explicitly state that it no longer applies the Spielberg "clearly repugnant" criterion, ${ }^{191}$ and that it does follow a "consistent with Board law" requirement. Apart from that, however, the other Spielberg requirements, that all parties to the dispute agree to be bound to the arbitrator's decision, and that the proceedings be "fair and regular," 192 should remain intact. The Board has given no indications that it wishes to abandon or redefine either of those requirements. The word "deferral" should be dropped from the Board's vocabulary in this area, to be replaced by either "arbitral postponement" or "arbitral adoption."

Under this policy, the Board would have reached the same decision that it did reach in Pincus Brothers, but would have stated the basis for the decision more accurately. It would have found the arbitrator's award "inconsistent" with the Act, rather than "clearly repugnant," on the grounds that the arbitrator's resolution of the statutory questions in the case was not consistent with the Board's reading of the applicable law. The Board would then have refused to "adopt" the award and would have decided the case itself. This new terminology should have little, if any, actual effect on Board decisions-it is simply a clearer way of describing what the Board has been doing for the past several years. It should be emphasized that this "new" Board policy by no means robs arbitration proceedings of their significance. The arbitration process continues to serve several important functions. First, it can be used to resolve most unfair labor practice cases that are based wholly on the inter-

188 See text accompanying notes 145-61 supra.

189103 L.R.R.M. 1113 (NLRB Jan. 8, 1980).

190 Id. 1114.

191 Spielberg, 112 N.L.R.B. 1080, 1082 (1955).

182 Id. 
pretation of contractual language. ${ }^{193}$ In such disputes, the arbitrator's award should be given a great deal of deference because, " $[w]$ here the question of unfair labor practice depends on contract interpretation, the expertise of arbitrators . . . is held to be superior to that of the Board which primarily considers the statutory issues." 194

Second, arbitration can be used to settle those cases in which the employee's statutory claim is frivolous. Employees fired for cause will not be able to use the Board as a second forum in which to seek reinstatement, because the General Counsel will not issue a complaint where the statutory claim lacks merit. ${ }^{195}$

Finally, the arbitrator's award serves two possible purposes when the grievance involves substantial statutory questions. First, where the arbitrator has considered and decided the statutory issues in a manner consistent with NLRB law, the Board will simply affirm the award as the decision in the case. Second, even where the arbitrator has not resolved the statutory questions, or the Board does not agree with his legal conclusions, it can still use the facts as found by the arbitrator and stated in his award as the record in the case. This record, supplemented by the briefs of counsel, can provide the basis upon which to decide the case.

\section{B. The Courts of Appeals}

The change in stated NLRB policy would have a more marked effect on the courts of appeals than on the Board. The policy shift would inform the courts that they should no longer apply their standards of review in a way that, in effect, obligates the Board to defer to arbitration awards that do not adequately resolve the statutory issues in a given case. Reviewing courts would not require the

193 The typical example of this type of dispute is the complaint alleging that an employer has taken unilateral action on an issue that is the subject of mandatory bargaining under the Act, with the response being that the collective bargaining agreement permits such action. See text accompanying notes 10-13 supra.

104 Stephenson v. NLRB, 550 F.2d 535, 538 n.4 (9th Cir. 1977).

195 The procedure under which the General Counsel and the NLRB review arbitration awards was recently discussed by Member John Truesdale:

[T] he bifurcated nature of the NLRB ... [ [means that] an independent General Counsel acts as the prosecutorial arm and decides whether to issue a complaint or dismiss a charge by applying precedents decided by the five-member Board. Thus, the only cases in which the Board can defer are those in which the General Counsel has concluded, in the precomplaint stage, that the Spielberg criteria have not been met. When such a case gets before the Board, the Board is not, of course, bound by the General Counsel's determination that deferral under Spielberg is not warranted. It is not surprising, however, that the Board more often than not reaches a similar conclusion.

Truesdale, supra note 62 , at 52 (emphasis in original). 
type of "fit" between the arbitrator's award and the Spielberg criteria that Pincus Brothers demands before upholding the Board's decision not to defer. By requiring NLRB deferral to awards that are "arguably . . . not inconsistent" with the Act, Pincus Brothers gives greater deference to arbitrators than it gives to the Board. ${ }^{196}$ Under the standard of review that this Comment proposes, however, the Board would be afforded the deference it deserves as the agency charged with enforcing the NLRA. In applying the Act to the facts of a given case, as found by the arbitrator, the Board will be allowed the broad margin of error that the Third Circuit standard now allows the arbitrator.

A Seventh Gircuit's panel's decision in St. Luke's Memorial Hospital, Inc. $v$. NLRB ${ }^{107}$ exemplifies the proper role that a court should play in reviewing NLRB refusals to defer. In that case, three hospital employees were discharged for leading a brief, unauthorized walkout. An arbitrator's award upheld the discharges, but the Board refused to defer to it on the grounds that the award was, inter alia, repugnant to the purposes and policies of the Act.198 The court affirmed this ruling, finding that "the arbitrator's award is arguably repugnant to the purposes and policies of the Act." 199 The "arguably repugnant" standard gives the Board the leeway it needs to enforce the NLRA effectively. Had it been applied in Pincus Brothers, the Board's decision not to defer would have been affirmed. Because the arbitrator's award in Pincus Brothers was arguably not inconsistent with the Act, it was also arguably inconsistent with-or repugnant to-it. Therefore, it seems reasonable to assume that the St. Luke's panel would have applied its "arguably repugnant" standard to uphold the Board's decision. If so, it should be remembered that the court would have simply been shifting the allowable margin of error in applying the Act from one authority to another. By allowing the Board to overturn an award because it arguably violates the Act, rather than allowing the award to stand because it is arguably reconcilable with it, a court recognizes the scope of the responsibility that is entrusted to the NLRB-the maintenance of labor-management peace and stability through the fair administration of the National Labor Relations Act.

$106 \mathrm{By}$ forcing the NLRB to accept an arbitrator's decision on a statutory issue unless there is no way to square that decision with the Act, 620 F.2d at 374, the Third Circuit is giving all of the discretion in deciding the case to the arbitrator. See notes 72-78 supra \& accompanying text.

197623 F.2d 1173 (7th Cir. 1980).

198 Id. 1177.

199 Id. 1178 (emphasis added). 


\section{CoNCLUSION}

The NLRB spent twenty-two years, from 1955 through 1977, developing an unneeded policy on deferral to arbitration awards. It has spent the last three years attempting to circumscribe that policy. Although it can be faulted for waiting so long to undertake this revision, and for failing to adequately articulate the changes it has made, the wisdom of its new approach seems readily apparent. The NLRB, not privately-selected arbitrators, should be able todetermine conclusively whether conduct runs afoul of the NLRA, because it is the public authority charged with administering the statute. The deferral policy designed in the Steelworkers Trilogy may contain the correct standards for the judicial review of contractual arbitration awards, but courts should not apply those guidelines to the Board's review of arbitration awards involving statutory-rights issues, as the Third Circuit apparently did in Pincus Brothers. To do so impairs the Board's ability to overturn the results of arbitration proceedings that have not properly considered those issues. The court should apply standards of review that foster, rather than frustrate, the protection of statutory rights. 


\section{APPENDIX}

TABLE I

Defarence to Arbitration Awaros Under Spielbetg; 1977-1980

$\begin{array}{cccc}\text { Year } & \begin{array}{c}\text { No. of Cases } \\ \text { in Which the } \\ \text { NLRB Deferred }\end{array} & \begin{array}{c}\text { No. of Cases } \\ \text { in Which the } \\ \text { NLRB Did Not } \\ \text { Defer }\end{array} & \begin{array}{c}\text { Percentage } \\ \text { of Cases in } \\ \text { Which the NLRB } \\ \text { Deferred }\end{array} \\ 1977 & 21 & 10^{2} & 16.7 \% \\ 1978 & 23 & 184 & 10.0 \\ 1979 & 45 & 126 & 25.0 \\ 1980 & 57 & 188 & 21.7 \\ \text { TotaI } & 13 & 58 & 18.3\end{array}$

1 United Parcel Serv., Inc. 232 N.L.R.B. 1114 (1977), enforced sub nom. Bloom v. NLRB, 603 F.2d 1015 (D.C. Cir. 1979); Jack Hodge Transport, Inc., 227 N.L.R.B. 1482 (1977).

2 Gimbel Bros., Inc., 233 N.L.R.B. 1235 (1977); Ford Motor Co., 233 N.L.R.B. 698 (1977); General Motors Corp. (Inland Div.), 233 N.L.R.B. 47 (1977), enforced, 616 F.2d 967 (6th Cir. 1980); United Stanford Employees, Local 680, 232 N.L.R.B. 326 (1977), enforced, 601 F.2d 980 (9th Cir. 1979); Owners Maintenance Corp., 232 N.L.R.B. 100 (1977), enforced, 581 F.2d 44 (2d Cir. 1978); Alfred M. Lewis, Inc., 229 N.L.R.B. 757 (1977), enforced, 587 F.2d 403 (9th Cir. 1978); Super Valu Xenia, 228 N.L.R.B. 1254 (1977); Chrysler Corp., 228 N.L.R.B. 486 (1977); Filmation Associates, Inc., 227 N.L.R.B. 1721 (1977); Versi Craft Corp., 227 N.L.R.B. 877 (1977).

3 The Kansas City Star Co., 236 N.L.R.B. 866 (1978); Lorain Div. of Koehring Co., 234 N.L.R.B. 1060 (1978).

4 Max Factor \& Co., 239 N.L.R.B. 804 (1978), enforced, 105 L.R.R.M. 2765 (9th Cir. Sept. 9, 1980); American Cyanamid Co., 239 N.L.R.B. 440 (1978); Ad Art, Inc., 238 N.L.R.B. No. 159 (Sept. 29, 1978), enforced, 106 L.R.R.M. 2010 (9th Cir. Dec. 9, 1980); Gould, Inc. (Switchgear Div.), 238 N.L.R.B. No. 88 (Sept. 28, 1978), enforced, 105 L.R.R.M. 2788 (10th Cir. Oct. 7, 1980); Greif Bros. Corp., 238 N.L.R.B. No. 30 (Sept. 20, 1978); District 1199E, Nat'l Union of Hosp. and Health Care Employees, 238 N.L.R.B. No. 8 (Sept. 7, 1978), rev'd and remanded, 613 F.2d 1102 (D.C. Cir. 1979); Pincus Bros., Inc.-Maxwell, 237 N.L.R.B. 1063 (1978), enforcement denied, 620 F.2d 367 (3d Cir. 1980); Davol, Inc., 237 N.L.R.B. 431 (1978), enforced, 597 F.2d 782 (1st Cir. 1979); The Mason \& Dixon Lines, Inc., 237 N.L.R.B. 6 (1978); Servair, Inc., 236 N.I.R.B. 1278 (1978), rev'd, 102 L.R.R.M. 2705 (9th Cir. 1979), petition for reh. granted, No. 78-2791 (9th Cir. 1980), opinion withdrawn and remanded, 624 F.2d 92 (9th Cir. 1980); Brewery Delivery Employees Local 46, 236 N.L.R.B. 1175 (1978); Owens Corning Fiberglas Co., 236 N.L.R.B. 479 (1978); Retail Clerks Local 324, 235 N.L.R.B. 711 (1978); T \& T Industries, Inc., 235 N.L.R.B. 517 (1978); Wilson Freight Co., 234 N.L.R.B. 844 (1978), rev'd, 604 F.2d 712 (1st Cir. 1979); Montgomery Ward \& Co., Inc., 234 N.L.R.B. 588 (1978); Douglas Aircraft Co., 234 N.L.R.B. 578 (1978), tev'd, 609 F.2d 352 (9th Cir. 1979); United Parcel Serv., Inc., 234 N.L.R.B. 483 (1978), enforcement denied, 104 L.R.R.M. 2612 (6th Cir. Oct. 12, 1979).

5 Atlantic Steel Co., 245 N.L.R.B. No. 107 (Sept. 28, 1979); Pacific Southwest Airlines, Inc., 242 N.L.R.B. No. 151 (June 14, 1979); United States Postal Serv., 241 N.L.R.B. No. 192 (May 3, 1979); Arnold Junior Fenton, Inc., 240 N.L.R.B. 202 (1979).

6 United Steelworkers Local 7450 (Asarco, Inc.), 246 N.L.R.B. No. 139 (Dec. 7, 1979); M \& B Contracting Corp., 245 N.L.R.B. No. 155 (Sept. 28, 1979); United States Postal Serv., 245 N.L.R.B. No. 115 (Sept. 28, 1979); Triple A Machine Shop, Inc., 245 N.L.R.B. No. 24 (Sept. 21, 1979); Brown Co., 243 N.L.R.B. No. 100 (July 30, 1979); Montefiore Hosp. and Medical Center, 243 
TABLE II

Deference to the Arbitration Process Under Collyer: 1977-1980

$\begin{array}{cccc}\text { Year } & \begin{array}{c}\text { No. of Cases } \\ \text { in Which the } \\ \text { NLRB Deferred }\end{array} & \begin{array}{c}\text { No. of Cases } \\ \text { in Which the } \\ \text { NLRB Did Not } \\ \text { Defer }\end{array} & \begin{array}{c}\text { Percentage } \\ \text { of Cases in } \\ \text { Which the NLRB } \\ \text { Deferred }\end{array} \\ 1977 & 2^{1} & 21^{2} & 8.7 \% \\ 1978 & 0 & 14^{8} & 0.0 \\ 1979 & 0 & 15^{4} & 0.0 \\ 1980 & 0 & 4^{5} & 0.0 \\ \text { ToTAL } & 2 & 54 & 3.7\end{array}$

N.L.R.B. No. 106 (July 25, 1979), rev'd in part on other grounds, 621 F.2d 510 (2d Cir. 1980); The Union Fork and Hoe Co., 241 N.L.R.B. No. 140 (April 17, 1979); Grane Trucking Co., 241 N.L.R.B. No. 19 (March 16, 1979); Oakland Scavenger Co., 241 N.L.R.B. No. 1 (March 15, 1979); Saint Luke's Memorial Hosp., Inc., 240 N.L.R.B. 1180 (1979), enforced, 623 F.2d 1173 (7th Cir. 1980); Sea-Land Serv., Inc., 240 N.L.R.B. 1146 (1979); Varied Enterprises, Inc., 240 N.L.R.B. 126 (1979).

7 Chemical Leaman Tank Lines, Inc., 251 N.L.R.B. No. 146 (Aug. 27, 1980); Gen. Tel. Co. of Mich., 251 N.L.R.B. No. 99 (Aug. 27, 1980); Bay Shipbuilding Corp., 251 N.L.R.B. No. 114 (Aug. 27, 1980); Botany 500, A Div. of RapidAmerican Menswear, Inc., 251 N.L.R.B. No. 75 (Aug. 26, 1980); Am. Bakeries Co., 249 N.L.R.B. No. 170 (June 13, 1980).

8 Pacemaker Yacht Co., 253 N.L.R.B. No. 95 (Dec. 18, 1980); Russ Togs, Inc., 253 N.L.R.B. No. 99 (Dec. 15, 1980); Aeronca, Inc., 253 N.L.R.B. No. 26 (Nov. 12, 1980); B \& L Motor Freight, Inc., 253 N.L.R.B. No. 14 (Oct. 27, 1980); Kahn's and Co., Div. of Consol. Food Co., 253 N.L.R.B. No. 4 (Oct. 10, 1980); The Motor Convoy, Inc., 252 N.L.R.B. No. 175 (Sept. 30, 1980); Hammermill Paper Co., 252 N.L.R.B. No. 172 (Sept. 30, 1980); United Parcel Serv., Inc., 252 N.L.R.B. No. 145 (Sept. 30, 1980); Herman Bros., Inc., 252 N.L.R.B. No. 121 (Sept. 30, 1980); Albertsons, Inc., 252 N.L.R.B. No. 81 (Sept. 29, 1980); Koppel, Inc., 251 N.L.R.B. No. 96 (Aug. 26, 1980); Babcock \& Wilcox Co., 249 N.L.R.B. No. 99 (May 23, 1980); Mitchell Bros. Truck Lines, 249 N.L.R.B. No. 51 (May 14, 1980); Colonial Stores, Inc., 248 N.L.R.B. 1187 (1980); Sachs Elec. Co., 248 N.L.R.B. 669 (1980); Pioneer Finishing Corp., 247 N.L.R.B. No. 182 (Feb. 21, 1980); General Warehouse Corp., 247 N.L.R.B. No. 142 (Feb. 14, 1980); Suburban Motor Freight, Inc., 103 L.R.R.M. 113 (NLRB Jan. 8, 1980).

1 Croation Fraternal Union, 232 N.L.R.B. 1010 (1977); Roy Robinson, Inc., 228 N.L.R.B. 828 (1977).

2 Timpte, Inc., 233 N.L.R.B. 1218 (1977), enforcement denied, 590 F.2d 871 (10th Cir. 1979); Saint Joseph's Hosp., 233 N.L.R.B. 1116 (1977); Texaco, Inc., 233 N.L.R.B. 375 (1977); McLean Trucking Co., 231 N.L.R.B. 706 (1977), vacated, 626 F.2d 1168 (4th Cir. 1980); C \& H Tire Serv., Inc., 230 N.L.R.B. 1173 (1977); Marion Power Shovel Co., Inc., 230 N.L.R.B. 576 (1977); Northeast Oklahoma City Mfg. Co., 230 N.L.R.B. 135 (1977), enforced, 631 F.2d 669 (1980); Int'l Bhd. of Electrical Workers, Local 367, 230 N.L.R.B. 86 (1977), enforced, 99 L.R.R.M. 2633 (3d Cir. June 21, 1978); Yellow Cab Co., 229 N.L.R.B. 1329 (1977), modified, 603 F.2d 862 (D.C. Cir. 1978); Sahara-Tahoe Corp., 229 N.L.R.B. 1094 (1977), enforced, 581 F.2d 767 (9th Cir. 1978); Columbus Foundries, Inc., 229 N.L.R.B. 34 (1977), enforced, No. 77-2012 (5th Cir. Jan. 27, 1978); United States Postal Serv., 228 N.L.R.B. 1235 (1977); Fairfield Nursing Home, 228 N.L.R.B. 1208 (1977); United Parcel Serv., 228 N.L.R.B. 1060 (1977), rev'd, Kohls v. NLRB, 104 L.R.R.M. 3049 (D.C. Cir. July 18, 1980); Sioux Quality Packers, 228 N.L.R.B. 1034 (1977); General Am. Transp. Corp., 228 N.L.R.B. 808 (1977); Ram Construction Co., 228 N.L.R.B. 769 (1977), enforced, 99 L.R.R.M 2633 (3d Cir. Dec. 5, 1977); Western Mass. Elec. Co., 228 N.L.R.B. 607 (1977), enforced as 
TABLE III

Deference to Arbitration Awards and the Arbitration Process: 1977-1980

$\begin{array}{cccc}\text { Year } & \begin{array}{c}\text { No. of Cases } \\ \text { in Which the } \\ \text { NLRB Deferred }\end{array} & \begin{array}{c}\text { No. of Cases } \\ \text { in Which the } \\ \text { NLRB Did Not } \\ \text { Defer }\end{array} & \begin{array}{c}\text { Percentage } \\ \text { of Cases in } \\ \text { Which the NLRB } \\ \text { Deferred }\end{array} \\ 1977 & 41 & 312 & 11.4 \% \\ 1978 & 23 & 324 & 5.9 \\ 1979 & 45 & 276 & 12.9 \\ 1980 & 5^{7} & 228 & 18.5 \\ \text { TotAL } & 15 & 112 & 11.8\end{array}$

modified, 573 F.2d 101 (Ist Cir. 1978); Cincinnati Bell, Inc., 227 N.L.R.B. 1930 (1977); Houston Chronicle Publishing Co., 227 N.L.R.B. 1829 (1977); International Union of Operating Engineers, 227 N.L.R.B. 1477 (1977).

3 Cooper-Jarrett, Inc., 239 N.L.R.B. 840 (1978); W-I Canteen Serv., Inc., 238 N.L.R.B. No. 87 (Sept. 28, 1978), enforcement denied, 606 F.2d 738 (7th Cir. 1979); New York Typographical Union No. 6, 237 N.L.R.B. 1241 (1978); Triangle Sheet Metal Works, 237 N.L.R.B. 364 (1978); United States Postal Serv., 237 N.L.R.B. 117 (1978); Meharry Medical College, 236 N.L.R.B. 1396 (1978); Brewery Delivery Employees, Local 46, 236 N.L.R.B. 1160 (1978); Safeway Stores, Inc., 236 N.L.R.B. 1126 (1978), enforced, 622 F.2d 425 (9th Cir. 1980); Los Angeles Marine Hardware Co., 235 N.L.R.B. 720 (1978), enforced, 602 F.2d 1302 (9th Cir. 1979); Youngstown Sheet and Tube Co., 235 N.L.R.B. 572 (1978); Loomis Courier Serv., Inc., 235 N.L.R.B. 534 (1978), rev'd on other grounds, 595 F.2d 491 (9th Cir. 1979); Milgram Food Stores, Inc., 235 N.L.R.B. 1 (1978); Helvetia Sugar Cooperative, Inc., 234 N.L.R.B. 638 (1978); National Rejectors Indus., 234 N.L.R.B. 251 (1978).

4 Native Textiles, 246 N.L.R.B. No. 38 (Oct. 24, 1979); Struthers Wells Corp., 245 N.L.R.B. No. 150 (Sept. 28, 1979); Union Boiler Co., 245 N.L.R.B. No. 93 (Sept. 28, 1979); Lewis Mittman, Inc., 245 N.L.R.B. No. 61 (Sept. 27, 1979); Amcar Div., ACF Indus., Inc., 245 N.L.R.B. No. 53 (Sept. 25, 1979); Southern Fla. Hotel \& Motel Ass'n, 245 N.L.R.B. No. 49 (Sept. 28, 1979); Precision Anodizing \& Plating, Inc., 244 N.L.R.B. No. 135 (Sept. 5, 1979); Garrett R.R. Car \& Equip., Inc., 244 N.L.R.B. No. 132 (Sept. 5, 1979); Kansas City Power \& Light Co., 244 N.L.R.B. No. 93 (Aug. 24, 1979); Container Corp. of Am., 244 N.L.R.B. No. 53 (Aug. 17, 1979); Wallace Metal Products, Inc., 244 N.L.R.B. No. 10 (Aug. 9, 1979); Southern Cal. Edison Co., 243 N.L.R.B. No. 62 (July 10, 1979); Ackerman Mfg. Co., 241 N.L.R.B. No. 106 (March 30, 1979); International Harvester Co., 241 N.L.R.B. No. 94 (March 29, 1979); Melones Contractors, 241 N.L.R.B. No. 3 (March 15, 1979).

5 Consolidation Coal Co., 253 N.L.R.B. No. 104 (Dec. 15, 1980); Interlake, Inc., 253 N.L.R.B. No. 76 (Dec. 9, 1980); International Bhd. of Electrical Workers, 251 N.L.R.B. No. 39 (Aug. 19, 1980); Caterpillar Tractor Co., 250 N.L.R.B. No. 89 (July 10, 1980).

1 See Appendix, Table I, note 1, supra \& Appendix, Table II, note 1, supra.

2 See Appendix, Table I, note 2, supra \& Appendix, Table II, note 2, supra.

3 See Appendix, Table I, note 3, supra.

4 See Appendix, Table I, note 4, supra \& Appendix, Table II, note 3, supra.

5 See Appendix, Table I, note 5, supra.

6 See Appendix, Table I, note 6, supra \& Appendix, Table II, note 4, supra.

7 See Appendix, Table I, note 7, supra.

8 See Appendix, Table I, note 8, supra \& Appendix, Table II, note 5, supra. 